\title{
Flooding dynamics within an Amazonian floodplain: water circulation patterns and inundation duration
}

Sebastien Pinel ${ }^{1,3,+}$, Marie-Paule Bonnet ${ }^{2,3}$, Joecila S. Da Silva ${ }^{1,3}$, Tania C. Sampaio ${ }^{1,3}$, Jérémie Garnier ${ }^{3,4}$, Thibault Catry ${ }^{2}$, Stephane Calmant ${ }^{3,5}$, Carlos R. Fragoso Jr. ${ }^{6}$, Daniel Moreira $^{7}$, David Motta Marques ${ }^{8}$, Frederique Seyler ${ }^{2,3}$

${ }^{1}$ RHASA, Amazon state University (UEA), Manaus, 69050-020, Brazil; sebpinel@gmail.com, jsdsilva@uea.edu.br, tainaconchy@gmail.com

2 UMR 228 Espace-DEV- Research Institute for Development (IRD), Maison de la télédétection, Montpellier, France; marie-paule.bonnet@ird.fr, frederique.seyler@ird.fr, thibault.catry@ird.fr

${ }^{3}$ International Joint Laboratory LMI OCE « Observatoire des changements Environnementaux », Research Institute for Development (IRD)/ University of Brasília (UnB), Campus Darcy Ribeiro, 70910-900, Brasilia, Brazil

${ }^{4}$ Institute of Geosciences (LAGEQ), University of Brasília (UnB), Campus Darcy Ribeiro, 70910-900 Brasília, Brazil; garnier@unb.br

${ }^{5}$ UMR 5566 LEGOS- Research Institute for Development (IRD), 14 Rue Edouard Belin, 31400 Toulouse, France ; stephane.calmant@ird.fr

${ }^{6}$ Federal University of Alagoas (UFAL), Center for technology, 57072-970, Maceio, AL, Brazil; ruberto@ctec.ufal.br

${ }^{7}$ Geological Survey of Brazil (CPRM), Av. Pasteur, 404, Urca, 22290-040 Rio de Janeiro, Brazil; daniel.moreira@cprm.gov.br

${ }^{8}$ Federal University of Rio Grande do Sul (UFRGS), Hydraulic Research Institute (IPH), CP 15029 Porto Alegre, RS, Brazil; dmm@iph.ufrgs.br

Correspondence to: Sebastien Pinel (sebpinel@gmail.com) and Marie-Paule Bonnet (mariepaule.bonnet@ird.fr)

Permanent address: ${ }^{+}$Engineering school of Alès (IMT Ales), Laboratory of Industrial Environment Engineering (LGEI), Rue Jules Renard, 30100 Alès, France.

\section{Key Points:}

- Interannual 2D-water circulation variations are controlled by main channel rising/receding rates, local runoff and prior inundation condition;

- Extreme floods induce positive (up to 40 days) or negative (up to -20 days) anomalies of inundation duration;

- Extreme floods only slightly modify velocity intensity and spatial distribution patterns.

This article has been accepted for publication and undergone full peer review but has not been through the copyediting, typesetting, pagination and proofreading process which may lead to differences between this version and the Version of Record. Please cite this article as doi: 10.1029/2019WR026081 


\section{Descriptive headings for key sections}

1. Introduction

2. Study zone

3. Material and method

The material and method part is divided in three parts. In the first part, we present both hydrological and hydrodynamics models, their input and how we will calibrate and validate these models. The second part details all the data required by both models and for the analysis: i) water level time series, ii) rainfall and meteorological data, iii) Bottom friction map , iv) topography and bathymetry data, v) flood extent from ALOS/PALSAR imagery, vi)velocity data. We describe where the data can be accessed and the preprocessing phases. The third part details the methodological approach for the analysis of water circulation pattern and inundation frequency

4. Results

In the first part of the results, we verify that the accuracy of the 2D-hydrodynamics model in terms of water level, flood extent and velocity. In the second part, based on the model output, we examine the seasonal patterns of water circulation and the flood duration during a hydrological year. Then, we inspect the influence of extreme events upon these patterns.

\section{Discussion}

The first part of the discussion deals with model performances, limitations and recommendations. The second part discusses of the seasonal and spatial distribution of water circulation pattern. The third part investigates the impact of extreme events upon water circulation and flood inundation. The fourth part debates about the potential impact of dams on flood extent and duration, and water circulation.

6. Summary and conclusion

7. Acknowledgement

8. References

9. Tables and figures

Abstract. Flooding dynamics across a medium-size (Janauacá Lake, $786 \mathrm{~km}^{2}$ ) floodplain system along the Amazon/Solimões River over a 9-years period (2006-2015) is studied through integration of remote sensing and limited in situ data in hydrologic-hydrodynamic modelling based on Telemac-2D model. We firstly detail the methodological approach and the modelling assessment in terms of water level, flood extent and velocity. The model correctly reproduces floodplain water level (Nash-Sutcliffe Efficiency=0.97), flood extent (averaged Threat Score=62) and horizontal velocity (Nash-Sutcliffe Efficiency >0.68). Model accuracy varies through the hydrological year. Then, we focus on seasonal and inter-annual spatial variability of water circulation and inundation duration. We highlight strong heterogeneities in water velocity magnitude between the different morphological domains of the floodplain, the highest velocities being encountered in the river-floodplain channel. In addition to topography, we emphasize the importance of the main channel and the local runoff in controlling the water circulation, at least during part of the hydrological year. From low water to early rising period, local runoff constrains the river incursion across the floodplain, while the rates of main channel rising/receding controls the flood duration. The comparison of several hydrological years highlights the interannual changes of these hydraulic controls and also the influence exerted by 
prior inundation conditions. While we observed few changes in water velocity distribution among hydrological years, the inundation duration is highly variable. Usually defined by maximum water level, extreme flood events may paradoxically induce positive (up to 40 days) but also negative (up to -20 days) anomalies of inundation duration.

Keywords: Amazon; Hydrometeorological hazards; Floodplain; Hydrological-hydrodynamics modeling; flood duration.

\section{Introduction}

Wetlands and floodplains (FP) cover about $14 \%$ of the Amazon Basin. In the lowland Amazon, FPs roughly occupy $800,000 \mathrm{~km}^{2}$ (Hess et al., 2015). They trap substantial amounts of sediment, about $15 \%$ of the total flux of the Amazon River flux in Óbidos (Fassoni-Andrade \& Paiva, 2019; Mangiarotti et al., 2013), yet large inter-annual variations are observed (Bourgoin et al., 2007). High primary production in FPs partly fuels the main channel with labile organic matter (Moreira-Turcq et al., 2013) and regulates $\mathrm{CO}_{2}$ or $\mathrm{CH}_{4}$ emissions (Abril et al., 2014; Amaral et al., 2018; Melack et al., 2004). They are essential components regulating flow propagation (Paiva et al., 2013; Richey et al., 1989). They support fisheries yields (Castello et al., 2018) which contribute significantly to local population livelihood and host several endangered species, such as fresh water dolphins recently added to the IUCN red list (Da Silva et al., 2018; Groenendijk et al., 2015). Amazonian FPs support one of the great Earth biodiversity reservoirs, yet poorly protected by current environmental policies in the Amazon (Castello et al., 2013). FPs are the most heavily impacted wetlands around the world (Tockner et al., 2008). In the last decades, the increase of in-river infrastructures, such as dams and waterways (Latrubesse et al., 2017) have modified hydrological continuity (Park \& Latrubesse, 2017). In coming years, FPs will be increasingly threatened by in-river infrastructures (Anderson et al., 2018; Forsberg et al., 2017; Ferreira et al., 2014). Conjointly with climate change, these expected development trends seriously endanger Amazon FP ecosystems and biodiversity (Castello \& Macedo, 2016).

Large seasonal variations of water level (WL) and highly smooth topography generate complex inundation patterns (e.g. Alsdorf, et al., 2007; Mertes 1997). Water quality and habitats characteristics are tightly related with FP water circulation. Flood amplitude and water velocity across the FP drive the inundation extent and key-variables such as depth, habitat connectivity and hydroperiod that control suspended and dissolved material fates and species distribution and interactions (Gurnell \& Petts, 2010). For instance, tree species distribution are not only controlled by substrate properties (Wittmann et al., 2006), but also by hydroperiod (Assis et al., 2014).

As shown by local hydrological studies, in-waters originate from the main channel and from local sources such as hyporheic water, local runoff and direct precipitation (Bonnet et al., 2008, 2017; Ji et al., 2019; Lesack \& Melack, 1995). Mertes (1997) defined the mixing area between these water sources as the perirheic zone. Its extent and location through the FP depend on water head distribution within the different ponds and significantly vary along the corridor and hydrological year (HY). Ji et al., (2019) highlighted that the water quality is highly controlled by 10-month rainfall accumulation and the rise/fall main channel rate (dh/dt).

Full 2D hydrodynamics models appear to be a good tool to study FP. However, they present the inconvenient to be time-consuming (Tonina \& Jorde, 2013). The LISFLOOD-FP hybrid model (Bates et al., 2010; Bates \& De Roo, 2000) based on simplified propagation equations, appears as a solution for modelling studies over Amazon FP. Based on this hybrid model or on simple flow routing schemes, several modelling studies have focused on FP hydrology: at regional scale (Luo et al., 2017; Paiva et al., 2013; Yamazaki et al., 2011), medium scale 
(Wilson et al., 2007), and local scale in the lowland Amazon (Bonnet et al., 2008, 2017; Lesack \& Melack, 1995; Rudorff et al., 2014a). These studies essentially focused on capturing flood extents (FE), WL, exchanged fluxes with the main channel and stored water volume throughout HY. Wilson et al. (2007) applied this model to describe the flooding of a medium-size reach $(240 \mathrm{~km})$ of the Solimões and highlighted the necessity to improve topographic data to succeed realistic simulations, especially during the flood receding period. Baugh et al. (2013) showed that vegetation removal from the available digital elevation model (DEM) SRTM V3 was promising to improve simulations. Going further, Yamazaki et al. (2012a) pointed out the necessity to capture most of the drainage inner-network features.

Only few studies involved a full 2D hydrodynamics model in the Amazon FPs that allow accurate velocity modelling. Frias et al. (2015) and Mendoza et al. (2016) coupled a sedimentation module to a hydrodynamics model to study the planform dynamics of anabranching structures. Finally, in the Amazon, water circulation and more specifically velocity analysis across the FP received limited investigations. Rudorff et al. (2014a,b) presented the most comprehensive study of water head distribution within a lowland Amazon FP but did not specifically address velocity patterns across the FP. Here, besides providing a general framework to mobilize heterogeneous data (in situ and various satellite products) into hydrodynamics floodplain modelling, this study provides interesting results upon water circulation (in terms of depth, water velocity, flood duration and frequency) in FP, especially regarding the impact of extreme climatic events.

In this study, we combine in situ information, remote sensing products and a hydrologichydrodynamic modelling to simulate flooding dynamic in a medium-size Amazonian FP and investigate spatial velocity patterns and flood frequency. We firstly present i) the methodology and the necessary datasets; ii) the hydrologic-hydrodynamic model performance in reproducing WL, FE and velocity. Then we employed this model to i) show spatial velocity patterns and flood frequency at seasonal scale and ii) examine the influence of extreme drought or flood events on velocity patterns and flood duration.

\section{Study zone}

The study site is the Janauacá FP $\left(3.200^{\circ} \mathrm{S}-3.250^{\circ} \mathrm{S}, 60.230^{\circ} \mathrm{W}-60.130^{\circ} \mathrm{W}\right.$, Amazon state, Brazil), a medium-size FP located on the right bank of the Amazon/Solimões River, $40 \mathrm{~km}$ upstream its junction with the Negro River. It is formed by the mixture of a varzea (the Northeast part) and a ria-lake, a composition rather typical along this Amazon/Solimões River reach. The main channel at this location generally exhibits a monomodal flood phase, usually rising regularly from November to reach its maximum in June at the Manacapurú gauge $\left(3.317^{\circ} \mathrm{S}\right.$, $60.583^{\circ} \mathrm{W}$ ) located $50 \mathrm{~km}$ upstream the FP. Eventually the rising period might be marked by a secondary peak, known as repiquete phenomena (Silva et al., 2012). The Amazon/Solimões River is loaded with suspended sediments from the Andes and commonly considered as a "white-water" river according to the Amazonian water typology established by Sioli (1984). The Janauacá FP is composed of a lake with fringing wetlands and inundated forest, linked to the main channel by a unique channel located at the FP northeastern side (Figure 1a-b). The FP and its local drainage basin extend over $786 \mathrm{~km}^{2}$ (Pinel et al., 2015). FE seasonally varies from less than $25 \mathrm{~km}^{2}\left(\sim 4 \%\right.$ of the FP extent) to $391 \mathrm{~km}^{2}$ ( $50 \%$ of the FP extent), reflecting WL change in orthometric height from less than $11 \mathrm{~m}$ to $24 \mathrm{~m}$. Like other lower Amazon FPs, flooding is ensured by several water sources: main channel through channelized flow or overflow is the main source by the end of the HY but local runoff, hyporheic water and direct rainfall are significant during the rising period (Mertes, 1997). From late low water period to mid rising period, the channel acts as an inlet until overflow starts when WL in the main channel is above levee crest (19.5 m) (Bonnet et al., 2017). The main channel water quality highly contrasts with water quality of small tributaries that is closer to "black water" properties 
with small suspended sediment load, poor in nutrients and rich in organic material (Bonnet et al., 2017; Sioli, 1984).

\section{Material and method}

\subsection{Modelling approach and settings}

The modelling approach relies on the offline coupling of two models, a hydrological model, which simulates runoff from the local upland watershed and a hydrodynamics model to simulate FP water circulation.

\subsubsection{Hydrological model}

The LUMP-FP model, developed and applied to the study site (Bonnet et al., 2017), was used to produce runoff from the upland local watershed as boundary condition for the hydrodynamic model (Figure 1b). Its main equations useful for this study are reported in appendices material. We used the same settings as Bonnet et al. (2017) to generate daily runoff for the study period extending from 11/01/2006 to 12/31/2015.

\subsubsection{Hydrodynamics model}

The TELEMAC-MASCARET system is freely available at www.opentelemac.org. This modelling system was designed for computational fluid dynamics (Hervouet, 2000) by the Laboratoire National d'Hydraulique et Environnement (LNHE). It is an hydrodynamics suite for massively parallel architectures (Moulinec et al., 2011) that uses an unstructured mesh allowing representing complex bathymetry. We specifically used its two dimensional (2D) hydrodynamic module (TELEMAC-2D v7p3) that simulates free-surface flows in the two dimensions of horizontal space. For more details, readers are referred to the TELEMAC-2D user manual (Lang et al., 2014). The main equations are reported in appendices material. In the Amazon region, this model was successfully applied to simulate estuarine regions hydrodynamics (Oliveros et al., 2008), the evolution of anabranching structures (Frias et al., 2015; Mendoza et al., 2016). It has also already been applied to model FP (Hostache et al., 2014; Smolders et al., 2015) and other large rivers (Vu et al. 2015).

The modeled domain was limited to the pixels whose elevation was lower than $29 \mathrm{~m}$ (4.6 $\mathrm{m}$ above the observed maximum $\mathrm{WL}$ ), i.e. the domain that contains the floodable area (Figure 1b). The initial pixels WL condition was set to the RL1 value at the 11/01/2006, and velocity was assumed null in the whole domain. The hydrodynamic model requires boundary conditions: i) water flow boundary condition (inflow from the local drainage basins at the outlets of local streams); ii) water level boundary conditions (WLBC) (inflow at cells in contact with the main channel) in which measured main channel WL is imposed. Hence, if the WL in WLBC cells is higher than the WL of the neighboring cells, flow from the river into the FP is computed. Conversely, outgoing flow occurs when WL in the neighboring cells are higher than the WL in the WLBC cells.

As mentioned above, LUMP-FP model provided the total discharge from the uplands. Based on sub-catchment area ratio, we distributed the flow among the different streams draining the local watershed. Diffuse runoff, direct precipitation and seepage also simulated by LUMP-FP were not considered since these contribute little to the FP water balance (Bonnet et al., 2017). Regarding WLBC, the combination of visual inspection of ALOS-1/PALSAR images and main channel WL allowed determining the zones associated with overflow and corresponding WL thresholds. Two areas were identified: WLBC1 (WL Boundary Condition 1) underwater for a WL of $19.50 \mathrm{~m}$ at $49 \mathrm{~km}$ downstream Manacapurú, and WLBC2 
underwater for a level of $20.00 \mathrm{~m}$ at $47 \mathrm{~km}$ downstream Manacapurú (Figure 1b). At these locations, we modified the levee elevations to match these elevation thresholds. At last, the junction between the main channel and the connecting channel constitutes the third WLBC3. WL at this three BC were linearly derived from the VSR gauge (VSR47, VSR49 and VSR52).

TELEMAC-2D model offers several options for calculation. Here, we chose the method of characteristics to simulate velocity advection and the propagation step is solved by the conjugate gradient method with a diagonal preconditioning which ensures numerical stability (Hess \& Stiefel, 1952). We used a constant viscosity set to $10^{-6} \mathrm{~m}^{2} . \mathrm{s}^{-1}$ and a constant water density set to $996.1 \mathrm{~kg} . \mathrm{m}^{-3}$ (Trevethan et al., 2016). Bottom friction was based on the Manning coefficient map. We used the Blue Kenue software (Canadian Hydraulics Centre, 2012) to generate a mesh of 224527 triangular elements with sides ranging from $23 \mathrm{~m}$ to $77 \mathrm{~m}$. Cobby et al. (2003) recommended using meshes with approximately equilateral elements to minimize mass balance error, variable element size to concentrate computational resource, and gradual transition between element size to maintain model stability. The model was run from $11 / 01 / 2006$ to $12 / 31 / 2015$ using a 30 s time-step on a multi-core cluster environment: the AltixXE 340 cluster platform, located at LNCC (Laboratório Nacional de Computação Científica, Brazil).

\subsubsection{Calibration and validation assessment}

As LUMP-FP model was fully validated for the study site (Bonnet et al., 2017), and as we used same settings and the same simulation period to analyze the results, further calibration and validation were not necessary for the hydrological model. However, we calibrated the hydrodynamic model (TELEMAC component) against WL measured at RL1 and RL2 from April 2007 (rising water) to January 2008 (low water) adjusting Manning coefficients by a trialand-error method. The model was validated over the whole simulation period in terms of vertical and horizontal accuracy. The reference datasets for the vertical validation were WL measured at RL1, RL2, VS1_564, VS2_564, and VS1_149. The horizontal validation consisted in comparing modeled and ALOS-1/PALSAR-deduced FEs.

Several classical statistics served to appraise model vertical accuracy: the mean and standard deviation of the difference between observed and simulated data (ME and SDE in meters, respectively); the Pearson correlation coefficient; the RMSE (m), the Nash-Sutcliffe efficiency (NSE) (Nash \& Sutcliffe, 1970). The NSE ranges from $-\infty$ to 1 . An NSE of 1 corresponds to an optimal fit, whereas NSE lower than 0 indicates that the observed mean is a better predictor than the model. The horizontal accuracy was assessed using the following skills scores (Wilks 2011): the Threat Score (TS) measures the model accuracy with a perfect score of 100; the bias index (BIAS) indicates the type of error (overestimation or underestimation); the False Alarm Ratio (FAR) measures the overestimation of simulated flooded areas with a perfect score of 0; and the Missed Flooded areas Ratio (MFR) measures the underestimation of simulated flooded areas with a perfect score of 0 . Those scores are determined using the following relations: $\mathrm{TS}=100(\mathrm{a} /(\mathrm{a}+\mathrm{b}+\mathrm{c})) ; \mathrm{BIAS}=100(1-(\mathrm{a}+\mathrm{b}) /(\mathrm{a}+\mathrm{c})) ; \quad \mathrm{FAR}=100(\mathrm{~b} /(\mathrm{a}+\mathrm{b}))$; $\mathrm{MFR}=100(\mathrm{c} /(\mathrm{a}+\mathrm{c}))$, where, $\mathrm{a}$ is the area that is both mapped and modeled as inundated, $\mathrm{b}$ is the inundated area modeled but not mapped, and $\mathrm{c}$ is the inundated area mapped but not modeled.

\subsection{Available datasets and consolidation towards modelling}

\subsubsection{Water level time series}

Daily WL data from two gauges of the Brazilian national network, namely Manacapurú gauge $\left(3.317^{\circ} \mathrm{S}, 60.583^{\circ} \mathrm{W}\right)$ with records since January 1972 and Iranduba gauge $\left(3.268^{\circ} \mathrm{S}\right.$, $60.215^{\circ} \mathrm{W}$ ) with records since January 2014 , were retrieved from the Brazilian water agency 
(ANA) website (http://hidroweb.ana.gov.br/). Two additional gauges were installed in the Janauacá FP at "RL1" $\left(3.424^{\circ} \mathrm{S}, 60.264^{\circ} \mathrm{W}\right)$ and "RL2" $\left(3.368^{\circ} \mathrm{S}, 60.193^{\circ} \mathrm{W}\right)$ with records from September 2006 to December 2015 (Figure 1b). All the gauges were levelled by a highprecision bi-frequency Global Positioning System (GPS) unit. The estimated accuracy of the height of the gauge zeros is $2 \mathrm{~cm}$. We also used WL data from nadir altimetry satellites: the ENVISAT/RA-2 altimeter operated by European Spatial Agency (2002-2010) and its followon French-Indian joint mission SARAL/ALtiKa altimeter in operation on the same orbit since 2013. Both furnish reliable measurements every 35 days upon water bodies (ESA, 2007, Verron et al., 2015). In the Amazon Basin, RA-2 accuracy ranged between several meters to less than $0.12 \mathrm{~m}$ (Silva et al., 2010). The measurement reliability of the ALtiKa altimeter was assessed in a few studies (Biancamaria et al., 2017; Maillard et al., 2015) outside of the Amazon Basin. Its accuracy ranges between 0.14 and $1.34 \mathrm{~m}$.

Following Roux et al., (2010), we produced 7 virtual stations (VS) (Figure 1b): VS1_564, VS2_564, VS1_149, VSR_149 and VSR_564 in the FP, and VSR_564 and VSR_149 in the main channel. The two latter being close $(1.6 \mathrm{~km})$, we merged both into a unique station denoted VSR hereafter. We used a linear relationship between Manacapurú WL gauge and VSR WL to produce daily main channel WL at VSR52 (located $52 \mathrm{~km}$ downstream from Manacapurú) (Roux et al, 2010). The comparison between altimetry data and in situ records enabled to correct or fulfil in situ measurements. RL1 data were checked against two VS (VS1_564 and VS2_564) that bracket the gauge, and RL2 was checked against VS1_149 and VSR52. The difference between observed WL and WL linearly interpolated from the framing VS was used to update in situ gauge levelling when necessary. The expected precision for the consolidated RL1 and RL2 gauges is $\pm 0.15 \mathrm{~m}$. However, we expected this accuracy to be degraded during exceptional droughts (2010) when gauges remained out of water.

RL1 WL reflects the main channel WL, starting to increase early in November until June when the recession phase is initiating. The mean RL1 WL peak is $23.30 \mathrm{~m}(\mathrm{SD}=0.90 \mathrm{~m})$ over 2006-2015 period. The average tidal amplitude over the same period was $11.05 \mathrm{~m}$ varying from $9.95 \mathrm{~m}$ for the 2014-2015 HY to $12.53 \mathrm{~m}$ for the 2011-2012 HY. Four extreme events mark the study period. Three are extreme floods when RL1 WL reached $23.95 \mathrm{~m}, 24.33 \mathrm{~m}$ and $24.36 \mathrm{~m}$ for the HYs 2008-2009, 2011-2012 and 2014-2015, respectively. One is an extreme drought when RL1 WL reaches its minimum 10.25 m during HY 2010.

\subsubsection{Rainfall and meteorological data}

We used daily rainfall data from six gauges from the Brazilian national network, downloaded from the ANA website (Figure 1a). Averaged rainfall on the FP was obtained weighting each gauge data series by the Thiessen polygon area $(\mathrm{Mu}, 2009)$. It is noteworthy to mention that the Manacapurú polygon represents by itself $76 \%$ of the total area. The average annual value over the 2006-2015 $\mathrm{HY}$ was $1821 \mathrm{~mm}$. $\mathrm{yr}^{-1}\left(\mathrm{SD}=612 \mathrm{~mm} \cdot \mathrm{yr}^{-1}\right.$ ) ranging from 711

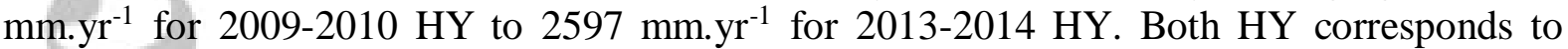
extreme event (Marengo et al., 2011; Espinoza et al., 2014). On the average, over the 20062015 period, the rainfall amount between October and April represents 77\% of the yearly amount.

The Brazilian national meteorological institute (INMET) provided hourly climatic data from the nearest meteorological station (Manacapurú, Brazil, Para state, $3.317^{\circ} \mathrm{S}, 60.583^{\circ} \mathrm{W}$ ) through its website (www.inmet.gov.br). We used the following meteorological parameters: insolation $\left(\mathrm{W} \cdot \mathrm{m}^{-2}\right)$, wind speed $\left(\mathrm{m} \cdot \mathrm{s}^{-1}\right)$, wind direction, air relative humidity $(\%)$, air temperature $\left({ }^{\circ} \mathrm{C}\right)$ and pressure $(\mathrm{hPa})$ useful for evapotranspiration computation in the hydrological modelling step. 


\subsubsection{Bottom friction map}

Following Rudorff et al., 2014a, we used the dual-season wetlands map of Amazon Basin (Hess et al., 2015) to define zones with same cover assumed to reflect friction properties in the FP. This product is available at the NASA Earth Observing System Data and Information System (EOSDIS) website (http://reverb.echo.nasa.gov/). It is based on mosaicked L-band SAR imagery, acquired by JERS-1 (1992-1998) at low water and high water seasons during the 1995-1996 HY. Hess et al., (2015) estimated the accuracy of the wetlands mapping to 93\% when compared with high-resolution videography samples. From this map, we retained 4 distinct classes: permanent water, shrubs, flooded forest and forest in spatial proportions of $44 \%, 14 \%, 21 \%$, and $20 \%$, respectively. Permanent water is likely overestimated as the wetlands map of the low water have been acquired during falling water (Pinel et al., 2015). The Manning coefficient attributed to each zone follows literature advises (Arcement Jr \& Schneider, 1989): 0.02-0.04, 0.03-0.06, 0.05-0.15 and 0.1-0.2 for permanent water, shrubs, flooded forest, and forest, respectively (Figure 2). It is noteworthy to mention that adjusting the Manning coefficient is part of the hydrodynamic model calibration step, as explained below.

\subsubsection{Topography and bathymetry data}

Both the hydrologic and hydrodynamic models required accurate topography data. In the Amazon, the most reliable source of topography data is originating from the Shuttle Radar Topographic Mission (SRTM), but it presents bias (Carabajal \& Harding, 2006; Rodriguez et al., 2006). We used the topography dataset produced by Pinel et al., (2015) for the study area. This dataset was derived from SRTMGL1 (30 m-resolution) dataset. The authors proposed to correct and improve as follow. The authors estimated the interferometric bias comparing SRTMGL1 elevation against ICEsat GLAS data extracted over non-vegetated regions and bathymetric data acquired at high WL. This bias was homogeneously subtracted to SRTMGL1 DEM. The authors combined the dual-season wetland map produced by Hess et al. (2015) with the height vegetation product derived from MODIS images produced by Simard et al. (2011) to estimate the vegetation-induced bias. This bias was removed. Final step consisted in interpolating the unbiased elevations, the ICEsat GLAS data, the bathymetric data using the ANUDEM v5.3 algorithm (Hutchinson, 2011) constrained by a drainage channel network deduced from Landsat imagery visual inspection. The produced topographic map presents a vertical accuracy of $1.7 \mathrm{~m}$ for a $30 \mathrm{~m}$ resolution (Pinel et al., 2015). Moreover, smoothing topography and ensuring hydrologic consistency by applying ANUDEM algorithm was an important step to further ensure numerical stability of the mesh processing and the hydrodynamics model. Several multi-error-removed and improved-terrain SRTM DEM at global resolution have been recently released (e.g. Berry et al., 2010; O'Loughlin et al., 2016; Yamazaki et al., 2017). Starting from a more accurate topographic dataset would certainly have helped to obtain better results at least in uplands. However, these products do not provide any topographic information below the SRTM water mask.

\subsubsection{Flood extent from ALOS/PALSAR imagery}

Evaluating the model performance requires FE observations. Due to limitations in retrieving water under forest, product based on optical imagery such as the high-resolution map of global surface water (Pekel et al., 2016) were not adapted to this study. As an alternative, Lband Synthetic Aperture RADAR (SAR) permits this detection (Arnesen et al., 2013; FerreiraFerreira et al., 2014; Frappart et al., 2005; Hess et al., 2003; Martinez \& Le Toan, 2007). Chapman et al., 2015 released a regional water mask based on an automatic classification from 
ALOS SCANSAR imagery, a JAXA mission that operated from 2006 until 2011. Unfortunately, this product presented weaknesses for this study: coarse resolution (3 arcseconds), few available scenes ( 9 dates spread out on 2007-2008), covering few WL (48\% of the WL variations), and a high grade of noise (average $17 \%$ of the watershed present no data value).

As a consequence, we performed a thresholding classification based on ALOS-1/PALSAR images, available through the ALOS Kyoto \& Carbon initiative (Rosenqvist et al., 2010) at the Alaska Satellite Facility website (https://vertex.daac.asf.alaska.edu/). We retrieved 24 scenes covering the whole range of WL conditions to better capture the flood pulse dynamics (Figure 3a) from 3 types of PALSAR products (Table 1). The FBS and FBD modes can have distinct footprints over the study area, namely Footprint 1 and Footprint 2 covering 38\% and 94\% of the zone, respectively (Figure 3b). The PLR mode provides images with a swath covering $94 \%$ of the watershed (Footprint 3). The classification process required the following steps: i) radiometric calibration of the data (conversion of the SAR signal in backscatter coefficients); ii) speckle filtering; iii) geometric corrections (orthorectification); iv) thresholding classification; v) classification improvement by consistency analysis; vi) quality assessment. JAXA provides the ALOS-1/PALSAR data at a treatment level in which the three first steps are already performed. The backscattering analysis and pixel classification were carried out using a manual thresholding method on the backscatter coefficients. During low water, with the low level of flooding, flooded pixels (open water such as main riverbeds or lakes) have low backscatter values and appear in black. Conversely, at high water, the signal of flooded pixels is a combination of open water (low backscatter values) and water under vegetation (high values backscatter resulting from the double-bounce effect). Hence, to map the presence of open water, we defined a single threshold at low water, while, we combined two thresholds during other hydrological period: one for the mapping of open water and one for vegetated water. The fifth step consists in imposing consistency between classified images to reduce the number of misclassified pixels. Hence, a pixel classified as "water" in an image with a given WL had to remain classified as "water" in any image associated with higher WL. Conversely, pixels classified as "non-water" had to remain classified "non-water" in images taken at lower WL. Finally, we controlled the classification quality against the FEs issued from Chapman et al., 2015. We compared scenes whose WL were similar $(<0.20 \mathrm{~m})$ and belonged to the same period (a total of 4 scenes). This analysis revealed a good agreement between both datasets (TS $>61$ ). Discrepancy can be partly attributed to the coarser resolution that increase the signal mixture in the pixels.

\subsubsection{Velocity data}

Averaged velocities of cross-sections were measured with an Acoustic Doppler Current Profiler (ADCP) (RDI instrument $1200 \mathrm{~Hz}$ ) at several periods of the water year at the Terra Alta (TA) location $\left(3.370^{\circ} \mathrm{S}, 60.214^{\circ} \mathrm{W}\right)$ and RL2 gauge location (Figure 1b). These two locations permitted measuring the channel discharges within a short distance from RL2 gauge. TA is located $3.10 \mathrm{~km}$ upstream from the RL2 WL gauge on the connecting channel. Each measure is based on 4 passes of each channel cross-section. At last, the velocity dataset consisted of 30 measures collected during the 2006-2011 period. This dataset covered all hydrologic periods. The expected accuracy in optimal conditions (laboratory) is $\pm 2 \mathrm{~mm} \cdot \mathrm{s}^{-1}$ (Teledyne RDI, 2013). The model performance in terms of velocity was appraised from the comparison between simulated and observed velocity in the connecting channel using statistics previously described. Simulated velocities in this channel were computed based on the integration of simulated horizontal field vectors $(\mathrm{U}, \mathrm{V})$ along the cross-section at both locations. 


\subsection{Analysis of water circulation pattern and inundation frequency}

To examine seasonal velocity patterns, we partitioned both space and time. An HY was subdivide into six hydrologic periods: i) late low water, ii) early rising water, iii) late rising water, iv) high water, v) falling water, vi) early low water. All hydrologic periods were defined from WL time-series and subsequently by date as proposed in Bonnet et al., (2017). For each hydrologic period of each HY, we selected 10 days. Using the 9-years simulation, we computed the temporal average velocity over these 10 days to produce velocity maps. Also, Bonnet et al., (2017) suggested that water quality contrasts across the FP may occur from different flooding dynamics. To verify this hypothesis, the FP was subdivided into three distinct domains: the lake area with fringing flooded forests and other wetlands (denoted LA, hereafter) from the south stream (denoted SS, hereafter) as suggested by these authors, and, we extended this partition to include the connecting channel (denoted CC, hereafter) (Figure 1a). We therefore propose an analysis of the mean velocity over the flooded area and over the three FP domains. By convention, positive velocities and slopes indicate water flowing from river to FP.

To examine spatial inundation frequency, for each mesh node and each HY, we computed the inundation duration, i.e. the number of days during which a node is flooded. The inundation frequency map was deduced from the average of the duration of inundation of each node over each simulated HY and reported to the length of the longest HY over the study period. For instance, $100 \%$ indicates a permanently inundated node for the longest HY.

The study period encompasses one extreme drought during 2009-2010 HY and several extreme floods (2008-2009 HY, 2011-2012 HY and 2014-2015 HY). We compared the average velocity over the total FE and over each sub-domain (SS, CC and LA) obtained for these HYs to those obtained for 2007-2008 HY considered as representative of "normal" hydrological conditions (Bonnet et al., 2017). We also computed the difference in inundation duration between the normal year and the extreme drought or flood HYs to build inundation duration anomaly maps.

\section{Results}

\subsection{Model performance assessment: WL, FE and velocity}

\subsubsection{Water level}

It is noteworthy to mention that the hydrodynamic model was poorly sensitive to the choice of the Manning parameter: the averaged RMSE varied from $0.37 \mathrm{~m}$ to $0.41 \mathrm{~m}$ when exploring the whole range of Manning values. We finally selected the values giving the lowest RMSE: $0.032,0.042,0.14$ and $0.18 \mathrm{~s} . \mathrm{m}^{-2 / 3}$ for permanent water, shrubs, flooded forest, and forest zones, respectively.

The simulated and observed WL are in good agreement at all gauges (Figure 4a-e). Global RMSE, NSE and correlation coefficient at the fifth stations over the entire period were $0.32 \mathrm{~m}$, 0.99 and 0.99 , respectively. Comparing to the accuracy of the bathymetry $(1.70 \mathrm{~m})$ and the amplitude of the flood wave $(11.05 \mathrm{~m})$, the RMSE value remained low. The validation upon VS (RMSE, NSE and correlation coefficient of $0.30 \mathrm{~m}, 0.99$ and 0.99 , respectively) remained similar to the ones upon in situ gauges (RMSE, NSE and correlation coefficient of $0.38 \mathrm{~m}$, 0.99 , and 0.99, respectively). The vertical accuracy also has temporal variations. RMSE, NSE and correlation coefficient presented the lowest values at low water with scores of $0.48 \mathrm{~m}, 0.75$, and 0.93, respectively. Best scores are obtained during rising water (RMSE, NSE and correlation coefficient of $0.17 \mathrm{~m}, 0.99$ and 0.99 , respectively). 


\subsubsection{Flood extent}

The overall horizontal accuracy TS was 62 (Table 2). The averaged positive BIAS (20), the higher averaged FAR (11) than the averaged MFR (34) suggested a slight FE under-prediction by the model (Figure5a-d). Nevertheless, the discrepancies magnitude showed temporal variations depending on the FP stage and the hydrologic period. For WL $>15 \mathrm{~m}$, i.e. during rising water, high water and early falling water, skills scores remained good (TS > 58). Similar values of positive BIAS (22-38) with low FAR (4-10) render a slight model underestimation. Conversely, for WL $<15 \mathrm{~m}$, the skills scores indicate for a model overestimation (Figure 5ab). Indeed, the BIAS turns into negative, FAR index increases (38-72) while MFR remains stable (slight increase from 34 to 46). Yet, the overall accuracy drops (TS < 48). This analysis also evidences geomorphological controls that confine inundation and some critical thresholds $(12 \mathrm{~m}, 15 \mathrm{~m}$ and $21 \mathrm{~m})$. Indeed, for very low WL, the inundation remains confined mainly to the inner drainage channels and small ponds in the LA-domain and in SS and CC-domains. Between 12 and 15 meters, the FE increases from $21 \%$ to $47 \%$ of the modeled domain, progressing essentially in the LA-Domain, and to a less extent in CC and SS domains. Above $21 \mathrm{~m}$ (that is slightly above the riverbank top) most of the inner natural levees are below water and inundation expands almost on the entire flooded domain.

\subsubsection{Velocity}

Computed and simulated CC-velocities are in satisfactory agreement (Figure 6a-b). The model correctly simulates the variation amplitude, with velocities values, ranging from -101.3 $\mathrm{cm} . \mathrm{s}^{-1}$ to $56.7 \mathrm{~cm} \cdot \mathrm{s}^{-1}$. Over the whole simulated period, the correlation coefficient and NSE were higher than 0.83 and 0.68 , respectively. The RMSE remained below $23.5 \mathrm{~cm} . \mathrm{s}^{-1}$. The outflow peaks can vary between $-24 \%(2010 \mathrm{HY})$ to $+28 \%(2015 \mathrm{HY})$. Conversely, inflow peaks remain similar with little inter-annual variations $\left(\mathrm{SD}=4.8 \mathrm{~cm} \cdot \mathrm{s}^{-1}\right)$.

\subsection{Patterns of water circulation and flood duration}

\subsubsection{Seasonal patterns}

The model simulated contrasted velocity magnitudes over the three domains, and high magnitude variation between hydrological periods (Figure 7a). Regardless the hydrological period, the highest velocity magnitudes are encountered in CC-domain with values over 5.0 $\mathrm{cm} \cdot \mathrm{s}^{-1}$ at high water, and the lowest in LA-domain with a mean value inferior to $1.7 \mathrm{~cm} . \mathrm{s}^{-1}$. Velocity magnitudes exhibit little variations in SS-domain $\left(0.8-1.7 \mathrm{~cm} . \mathrm{s}^{-1}\right)$, while they range between $5.1 \mathrm{~cm} \cdot \mathrm{s}^{-1}$ during early low water $\left(0.2 \mathrm{~cm} . \mathrm{s}^{-1}\right.$ at late low water) and $20.1 \mathrm{~cm} . \mathrm{s}^{-1}(6.2$ $\mathrm{cm} \cdot \mathrm{s}^{-1}$ ) during high water in CC-domain (LA-domain). In SS-domain, the velocity magnitude is maximum during the falling period.

The water circulation patterns are highly variable along the HY (Figures 7b-g). Until early rising water, CC-domain acts as an inlet. From late rising water to falling water, water circulation in the three domains is organized toward the main channel. At early low water, the river flows into the LA- and SS-domain. Between early low water and early rising water, the rise of the local runoff counterbalances the increase of rivers-to-FP discharge, limits the river incursion into SS-domain and spreads over LA-domains. Velocity magnitudes in SS and CCdomains, where the flow is well-bounded, are greater than in LA-domains except during high water (Figure 7a). The moving frontier position between main channel water and water coming from the local drainage watershed is well-defined, around the mid-course of SS-domain. During late rising water and high water, overflow induces a significant velocity magnitude 
increase in the north-eastern part of LA-domain and in CC-domain, and also a circular water circulation. At falling water, flows are organized towards the main channel in all domains.

As expected, water circulation results in contrasted inundation frequency across the FP (Figure 8). On average over the studied period, SS and CC-domains and the inner-channels in the LA-domain remain inundated all year-round. Some ponds located in the north-west of LAdomain, but also some located in the CC-domain also remain flooded all year-round. Inundation frequency is reduced by $20 \%$ (about 2 months and a half) in the flat LA-embayment and small bays along SS-domain. The inundation duration of levees and creeks is less than 6 months while some topographical features remain free of water all year-round, leaving some wetlands disconnected a large part of the HY.

\subsubsection{Extreme events impact upon these patterns}

Temporal velocity magnitude averaged over the whole FP follows a seasonal monomodal pattern that repeats each year (Figure 9a). The velocity magnitude increases from November to June and then decreases until the end of the year. Impact of the extreme water year is visible, in terms of velocity magnitude and peak timing and duration, when compared to "normal" HY (Figures 9b-d). During normal HY, velocity magnitudes in CC-domain range between $5.7 \mathrm{~cm} . \mathrm{s}^{-}$ ${ }^{1}\left(10^{\text {th }}\right.$ percentile during rising water and falling water $)$ and $19.2 \mathrm{~cm} \cdot \mathrm{s}^{-1}\left(90^{\text {th }}\right.$ percentile at late falling water), with a mean value of $13.0 \pm 5.3 \mathrm{~cm} \cdot \mathrm{s}^{-1}$. Velocity magnitude presents two limited peaks in December and February. By the end of March, CC-velocity magnitudes start increasing to reach a plateau with high value greater than $15.0 \mathrm{~cm} . \mathrm{s}^{-1}$ corresponding to the overflow period, this plateau standing until the end of July. Early in August, the velocity magnitude sharply decreases and abruptly rises again by the end of this month reaching a maximum around mid-September. During extreme HYs (here 2009-2010 and 2011-2012), this seasonal pattern is mainly conserved, but the timing of peaks is significantly different, as well as the velocity magnitude values. The velocity magnitude ranges between $2.1(9.0) \mathrm{cm} . \mathrm{s}^{-1}$ and 18.1 (20.1) $\mathrm{cm} . \mathrm{s}^{-1}$ during drought (flood) years. During drought, we only observe one velocity magnitude peak in February during the rising period, it is anticipated of about one month when compared with normal or extreme flood years first peak, but with comparable velocity magnitude. The latter steadily increases until mid-April before reaching a plateau which duration is reduced by one month and a half when compared to normal year. Also, the falling period peak is anticipated, and velocity magnitudes reach higher values. During extreme flood year, velocity magnitude increases steadily throughout the rising period, and peaks are less marked. The velocity magnitude reaches rapidly a plateau lasting longer than during normal year by about 2 months and during which velocities values are higher. The velocity peak that occurs mid-September during normal year is delayed by the end of this month. In the SSdomain, the velocity magnitude variation is marked by three distinct periods. During the normal year rising period, it forms a first peak, with velocity magnitude steadily increasing from November to December, and then decreasing until March. It remains rather constant from this month until August when it starts to increase, reaching a maximum by mid-September before decreasing again. During extreme flood year, the velocity magnitude temporal evolution follows normal year evolution from November to April, but significantly rises from May to July. By the end of the year, the evolution is similar as normal year with a 15-day delay. Whatever the considered year, velocity magnitudes in LA-domain remain small (less than 1 $\mathrm{cm} . \mathrm{s}^{-1}$ ) except from April to August. We observe only small differences between drought and normal year in terms of timing and variation amplitude. However, during flood years, velocity magnitudes reach higher value $\left(8.0 \mathrm{~cm} . \mathrm{s}^{-1}\right.$, i.e. $\left.+197 \%\right)$ and the plateau with higher velocity lasts longer from mid-March to the end of August. 
Extreme drought or flood events also impact the inundation duration across the FP (Figure 10a-e). Compared to normal HY, the inundation duration during the 2009-2010 drought was reduced by more than a month in a large region of the LA-domain and in the small creeks and bays along the SS-domain (Figure 10a and 10b). Interestingly, extreme floods impact varies as a function of the considered event. As expected, extreme floods cause an increase of the inundation duration for pixels located along the margins of the different domains (LA, CC, SS), that are not inundated or only immerged a couple of months during a normal HY. For pixels in the LA-domain, which are usually flooded more than half a HY, the inundation duration may reduce up to 20 days (e.g. during 2011-2012 Figure 10d) or increase up to 50 days (e.g. during 2014-2015 Figure 10e) or only up to 20 days (e.g. 2008-2009 Figure 10c). In addition, in the CC and the central part of the SS domains, the inundation duration increases between 10 and 20 days as a function of the HY.

\section{Discussion}

\subsection{Model reliability}

\subsubsection{Model performances}

Over the whole study period, the simulated WL and FE were in good agreement with the observations. However, both vertical and horizontal assessment underlined a degradation of accuracy during low water, while the model correctly reproduces WL and FE during rising water, high water and early falling water. Other studies about Amazonian FP hydrodynamics also reported a diminution of the vertical accuracy between low water and high water (e.g. Wilson et al., 2007; Rudorff et al., 2014a; Yamazaki et al., 2012; Paiva et al., 2011b). This deterioration at low water is likely due to an under-representation of the inner-drainage channels that organize the flooding and the falling period as suggested by Wilson et al., (2007), Trigg et al. (2012) and Rudorff et al., (2014a). Besides, the quality of the observation datasets should slightly lower during low water: i) the RL1 and RL2 could have remained out of water ii) the probability of mixed water-non water pixels increases degrading the quality of ALOS/PALSAR images classification. In addition, at the lowest resolution $(30 \mathrm{~m})$ in the PLR mode, a higher number of mixed pixels should be encountered. During high water, our analysis highlighted slight vertical and horizontal underestimation that we associate to little inaccuracies of bank elevations or locations for the WLBC, leading to slight overflow underestimation.

The model was able to simulate the $\mathrm{CC}$-velocities variations. It also reproduces that the channel acts as inlet only during the early rising period and that overflow is the main water inflow pathway for the Janauacá FP. Once overflow occurs, flow is reversed in the channel and the FP exports water into the main channel, as already mentioned in Bonnet et al., (2017). The overflow period also corresponds to the maximum exportation flow, even while FP WL is still increasing. However, the model delays the overflow onset of roughly 15 days, more likely because levee elevation is slightly overestimated. Levee overestimation also induces a slight overflow underestimation that is reflected in the computed velocities at high water. Accurate levee elevation is difficult to obtain from the available topography dataset (SRTM) but is crucial to correctly represent river-FP exchanges. Here, it was deduced from visual inspection of ALOS/PALSAR images and main channel WL. 


\subsubsection{Limitations and recommendations}

The analysis of the model performance evidenced the topographic controls. Hence, modeler should take into account both the accuracy and the resolution of input topography. Here, visual inspection of ALOS-1/PALSAR images allowed detecting several channels whose width remains inferior to the minimum mesh edge size $(23 \mathrm{~m})$. We might expect large improvement of DEM from the new generation of remote sensing products, such as Sentinel constellation. Sentinel 1/2 acquired data offers better spatial resolution (10 m against $30 \mathrm{~m}$ for Landsat) and acquisition frequency (one image every 12 to 6 days) that could enable to construct a much more realistic DEM and accurately detect the levee elevations. A method for integrating variable flood extent data with DEM is needed, but this technique is not yet established. In addition, forested wetlands present pronounced microtopography that consists of hummocks and hollows (Day et al., 2007) that obviously affect the local water velocity field. With a 23mmesh resolution, the model likely does not capture such fine-scale topographic controls. However, these features are taken into account through the roughness coefficient that is adjusted during the model calibration.

This study highlighted the necessity of controlling the quality of the validation datasets. Indeed, both observed WL and FE suffer from degradation at low water preventing robust validation at that period. As in most of hydrodynamics studies, simulated velocity fields cannot be fully (spatially and temporally) validated with observations. Nevertheless, velocities validation step indicates that $\mathrm{CC}$-velocities are correctly estimated giving confidence for the other FP domains. Besides, the identified spatial patterns of average velocity seem to be realistic when compared to field knowledge. Indeed, the evidenced patterns support the interpretation of electrical conductivity spatial distribution proposed in (Bonnet et al., 2017, Figure 10). To go further, comparison with observed velocity would be required in other part of the FP. However, velocity being very low, their direct measurement is impossible with field device such as ADCP and drifting buoys experiments would be required.

The presented model could have been more sophisticated by including the evolution of bottom shear stress or the wind effect. Indeed, the vegetation impact upon velocity distribution is handled through a relatively simple approach, as we adopted a time-constant cover map while low herbaceous vegetation is growing seasonally. Besides, no data upon vegetation growth were available for this study. Regarding the wind effect, Amaral et al. (2018) showed in the same floodplain that sites with more wind exposure have different biogeochemical characteristics than wind protected areas. However, 1-year in situ measurements reported a low wind intensity with little variations $\left(1.10 \pm 0.96 \mathrm{~m} . \mathrm{s}^{-1}\right)$. Both variables may have impact on our results, but the topography data remain the primary source of model uncertainty.

At last, this model simplifies the modelling flow as it assumes vertical homogeneity. In the same study zone, based on conductivity data analysis, Bonnet et al., (2017) suggested that a slight vertical stratification should occur during rising and high water. Thus, to simulate sediment or solute distribution, a 3D version is advisable.

Despite these limitations, the good agreement between observed and simulated data, in terms of WL, FE and velocity, suggests the hydrological-2D-hydrodynamics modeling is sufficient to capture the flow in the floodplain. Finally, our modelling approach only required a very limited set of in situ data (bathymetry and velocity observation). Bathymetry is required to best retrieve the inner floodplain channels, while observed velocity observations are necessary to calibrate/validate velocity computation. Several studies show the possibility to partly reconstruct bathymetry at least for seasonally inundated areas from temporal series of satellite-based FE and WL (Hernandez \& Armstrong, 2016) or may be adjusted through the model calibration step (Yamazaki et al., 2012). Hence, our methodological framework can be transferred to any floodplain location in the world. 


\subsection{Water circulation pattern: seasonal and spatial distribution}

The seasonal and spatial velocity magnitude evolution and the distribution of inundation duration reported in this study reveal the complexity of water circulation patterns across the FP as already reported in Mertes (1997) and Alsdorf et al. (2007) at regional scale and in Rudorff et al. $(2014 \mathrm{a}, \mathrm{b})$ for a larger FP system in the lower course of the Amazon River. The inundation extent, duration and velocity magnitude in the different domains of the FP are only partly controlled by topography.

As expected, current CC-velocities magnitude is significantly higher where the flow is well constrained by levees. Velocity magnitudes are also greater in SS-domain than in LA-domain, but not during late rising water and high water when overflow occurs in the north-westward region of LA-domain (Figure 9a-d). Our results suggest the importance of hydraulic controls. During the early rising period (WL $<17 \mathrm{~m}$ ), water slopes in CC are positive and in opposite direction than those in SS and in a higher magnitude $\left(0.6 \mathrm{~cm} \cdot \mathrm{km}^{-1}\right.$ in $\mathrm{CC}$ against $-6.8210^{-4}$ $\mathrm{cm} . \mathrm{km}^{-1}$ in SS). The river incursion into the channel is limited by runoff from the local watershed which is maximum during this period and spreads rather over the LA-domain than going up along the SS-domain. However, later in the rising period $(17<\mathrm{WL}<20 \mathrm{~m})$, when rainfall amount and runoff from the watershed already diminished, slopes equilibrate between the two domains allowing the river progression along SS.

For WL higher than $20 \mathrm{~m}$ (high water), corresponding roughly to the overflow period, there are no velocity magnitudes differences between rising and receding periods, and the velocity magnitudes in $\mathrm{CC}$ are comparable to those found during the falling period. It is also the period corresponding to maximum velocity in the LA-domain, especially in the north-eastern region. At this period, flows have a circular pattern driven by topography and hydraulic controls exerted by SS-domain. In LA-domain the circulation during the rising and early falling periods may be considered as return flow, when either the local runoff or the Amazon/Solimões River acts as hydraulic barriers. That the Amazon/Solimões River partly blocks the FP output is not surprising as such effect is already reported for Amazon River tributaries (Paiva et al, 2013) that present much higher discharge than the $\mathrm{CC}$. This effect was also observed in the Orinoco Basin between the main stream and its tributaries (Rosales et al., 2008). However, the role of local runoff upon river incursion is much less documented. Based on regional remote sensing analysis, Mertes (1997) mentioned the role of FP water saturation prior to main channel inundation as a main factor to explain the river incursion extent across the FP. Besides, the electrical water conductivity distribution in the FP shown in Bonnet et al. (2017; figure 10) supports our findings. Because the river water conductivity highly contrasts with that of the local runoff or direct rainfall, they used conductivity as tracer to track the river incursion and mixing of these different water sources. Especially, they showed that the river incursion along SS is limited during early rising water while it reaches upper reaches in the South direction only late in the rising period. They also pointed out that LA-domain is a mixture of previous year remaining water at a beginning of HY, runoff water from SS and river waters during rising water. During high water, LA-domain waters reflect river condition.

During late high water and falling water, the sharp decrease followed by an abrupt rise in $\mathrm{CC}$-velocity magnitude during mid-falling water is likely due to hydraulic controls exerted by the main channel. The sharp CC-velocity decrease occurs when the slope between CC and the main channel becomes almost null (CC-slopes of $-0.2 \mathrm{~cm} . \mathrm{km}^{-1}$ during the early falling period $(17<\mathrm{WL}<20 \mathrm{~m}))$. In this condition, the Amazon/Solimões acts as a hydraulic barrier. Then, the abrupt rise is likely due to the Amazon/Solimões flood receding phase that starts before that of the Janauacá FP. As a consequence, it induces a strong gradient between FP WL and main channel WL. Indeed, during late falling period (WL $<17 \mathrm{~m}$ ), we compute CC-slope of $5.4 \mathrm{~cm} \cdot \mathrm{km}^{-1}$. FP WL follows the river WL. This hydraulic gradient may also be the main driver of SS-velocity during falling water. However, during this period, LA-domain loses its direct 
connection with the main channel (the main channel margins) and velocity falls back to moderate velocity $\left(<2 \mathrm{~cm} \cdot \mathrm{s}^{-1}\right)$. Our findings support Alsdorf et al. (2007) statement upon the difficulty to retrieve water circulation from FP topography only. They also confirm those obtained by Ji et al, (2019) on another Amazonian FP that highlighted a strong interplay between local rainfall/runoff and river rising/receding rate.

However, despite its complexity, some characteristics of water circulation repeat each year as conceptually summarized in Figure 11 . From low water to early rising period (WL $<17 \mathrm{~m}$ ), the river incursion into the connecting channel reverts the natural topographic-induced flow and is constrained by local runoff (maximum during this period). Part of the river water spreads over the LA-domain. At late rising water and high water (WL>20 m), overflow causes an increase of velocity in the floodplain (mainly in the LA-and CC-domain) and circulation is likely organized as circular flow. During the falling period, the Amazon/Solimões River acts as a hydraulic barrier exerted on the FP outflow. At late flushing and early low water periods, flows are driven through little channels by topography.

Seasonally and spatially contrasted velocities between the different FP domains also imply spatially contrasted inundation duration and water residence time in the FP. As expected, the LA-domain always presents lower velocities than SS and CC-domains, except during high water, and thus water residence time in this domain is greater (Bonnet et al., 2017 and this study). Hence, we might expect contrasted biogeochemical processes and planktonic microorganisms distribution in the FP. Amaral et al. (2018) proposed a detailed study of carbon emission from the Janauacá FP. Their study handled two measurements stations: one is in the LA-domain, the other at the frontier between SS and CC-domains. The authors interpreted the strong water quality and primary and respiration rates differences by the impact of wind exposure they observed between these two stations. We also suggest that differences between their two stations is linked to water circulation that controls the mixing of the river, runoff water and the dilution of previous year water volume (Bonnet et al., 2017 and our findings). Indeed, the wind exposed point (Amaral et al., 2018, figure 1) located in LA-domain is less influenced by main channel water during the early and mid-rising period and presents lower velocities than wind protected station and is "totally" influenced by the main channel water during high water. This could partly explain the contrast they found in terms of light extinction coefficient, which is related to suspended solids load, and in integrated primary and respiration rates.

\subsection{Extreme events impact upon water circulation and flood inundation}

During hydrological extreme events, the seasonal velocity patterns are relatively similar to those observed during normal year, but amplitude and peaks timing are significantly different. The study period only encompasses one drought HY, thus it is difficult to establish some general rules. Based on our findings for the 2009-2010 drought, the velocity magnitude is essentially modified in SS-domain, where slightly higher velocities are encountered during the rising and late rising period and the inundation duration is reduced, especially in the LAdomain where the topography is relatively flat.

Conversely, the study period encompasses three important floods events, during 20082009, 2011-2012, 2014-2015 HY. Seasonal velocity patterns were relatively reproducible between these three flood events: the period with high velocity magnitude (plateau) lasts longer than during normal years, the velocity during the rising period in CC and SS are not drastically modified but the falling period is significantly delayed. The flood amplitude obviously controls the inundation extent and thus controls the inundation duration of pixels with bottom elevation above the "normal" maximum flood amplitude. On the other hand, changes in inundation duration for pixels that are "normally" flooded differ between flood events, especially in the 
LA-domain. These differences reflect FP saturation conditions prior to inundation (i.e. the initial FP water volume) and the strength of the hydraulic control exerted by the Amazon/Solimões River, which vary inter-annually. At the beginning of the 2014-2015 cycle, the minimum WL was roughly 2 meters above that of 2008-2009 and 2.5 m above that of 20112012 (Figure 4a). We appraised the strength of hydraulic control by the Amazon/Solimões River though rising and receding water rates for WL ranging between 14 and $20 \mathrm{~m}$ (Figure 4a). The rising rate was the highest during the 2011-2012, and the smallest during 2014-2015 HY. The receding rate was the highest during the 2014-2015 HY and was equal during the 20082009 and 2011-2012 HYs. Thus, the difference of positive inundation duration anomaly observed between 2014-2015 HY and 2008-2009 HY might be explained by the prior inundation condition in 2014-2015. The negative inundation duration anomaly during 20112012 HY should result from higher rising water rate while receding water rate is comparable to $2008-2009 \mathrm{HY}$.

Therefore, flood or drought strong events, beside modifying the proportion between the different sources of water in the FP (Bonnet et al., 2011, 2017), also imply significantly different water circulation patterns and flood duration that may have consequences upon biogeochemical processes, planktonic micro-organisms species distribution, and sediment transport. For instance, based on the velocity analysis and the Hjulström diagram (Hjulstrom, 1939), we might expect clay, silt transportation and sand deposition (particles diameter $<0.15$ $\mathrm{mm}$ ) in the CC and SS domains. Sediment particles with diameter greater than $0.15 \mathrm{~mm}$ (i.e. sand or gravel) will always deposit in the SS and LA domains. The CC-velocity magnitude allows transporting these bigger particles throughout most part of the HY. CC-velocity reached during extreme year during falling period permits sand erosion, and that flood event facilitates the transport (and then the deposit) of sand particles in the LA-domain. These results are in line with Rudorff et al., (2018) findings that related sediment transport into FP and net storage intensification with the increased frequency of flood events in the last decade. Conversely, drought will prevent from sand transport in the LA.

\subsection{Potential impact of dams on flood extent and duration, and water circulation}

Our results suggest that beside local runoff, both amplitude and dynamics (rising and receding rates) of water level variation in the associated river (in our study, the main channel) are important controls of flood extent and duration in floodplains. These results are important while considering the potential impact of dams on the flood extent and duration downstream. Still largely underexploited in the Amazon basin, hydropower generation is expected to drastically increase in the next few years with the construction of several dams across the basin (Finer \& Jenkins, 2012; Latrubesse et al., 2017). Power generation and regulation require damspecific discharge management regime in function of the dam-impoundment specifications (e.g volume, inflow), the associated river geomorphological and hydrological characteristics and induce important change in WL variations, flood extent and flood period (Forsberg et al., 2017). Because each discharge management regime differs, but also because dams will be distributed over several rivers with contrasted hydrological regimes, they will not only impact water level range of variation but also water level rising and receding rates in the associated rivers and downstream with hardly foreseeable impacts on flood duration. Thus, as mentioned in Latrubesse et al., (2017), concertation between countries and dams' managers is required to maintain the river's regime as close as possible to their natural state.

\section{Summary and conclusion}

Based on a hydrologic-2D hydrodynamic modelling (LUMP-FP and Telemac-2D), we investigate flooding dynamics across a medium-size Amazonian floodplain (FP) system (786 
$\mathrm{km}^{2}$, including the local catchment). The proposed approach integrates in situ information and remote sensing into a hydrologic-hydrodynamic model to simulate a 9-years period (20062015) that encompass three extreme floods and one drought events. The model correctly reproduced water level (WL), flood extent (FE) and velocity. However, as in other 2D modelling studies conducted in the Amazon region, its accuracy varies along the hydrological year (HY). Indeed, misrepresentation of inner-channels network and imprecision in levee elevation slightly lower the accuracy of the model at low water period and high water, respectively.

The analysis of velocity spatiotemporal patterns highlights strong heterogeneities in water velocity magnitude between the different morphological domains of the FP. The river-FP connecting channel (CC-domain), where flow is well constrained by levees, presented the highest velocities, and the large embayment (LA-domain) in the northern-westward direction the lowest, except during high water. However, topography only partly controls the water circulation. Flows are also constrained by the interplay between main channel and local runoff at least part of the HY. Comparing several HYs highlights the interannual changes of these hydraulic controls in function of main channel rising and receding rates, the local runoff and the influence exerted by prior inundation conditions.

Seasonally and spatially contrasted velocities across the FP imply spatially contrasted inundation duration. Drought essentially modifies SS-domain velocities, where higher values are encountered during the rising and late rising periods. It also reduces the velocity in the LAdomain during the high water, and consequently every mixing process in this area. The inundation duration is reduced, especially in the flat LA-domain. Flood events slightly affect the velocity magnitude at late rising water and high water (overbanking) and alter the duration of seasonal velocity patterns. While the flood amplitude controls the inundation extent, the rate of the rising/receding water in the main channel and the prior inundation conditions control the inundation duration in the FP during flood events. Consequently, extreme flood amplitude does not necessary implies longer inundation duration. The latter results are also important while considering the potential impact of dams. Indeed, hundreds of spatially distributed dams across the Amazonian basin will not only affect the WL range in the dammed rivers but also the rising and receding rates of the associated rivers and far downstream with hardly foreseeable impacts; concertation between countries and dams manager is thus required to maintain the river's regime as close as possible to their natural state.

The seasonal pattern of water circulation and inundation duration exhibits strong interannual variations. As these hydrodynamic features are key factors upon suspended solids transport, biogeochemical processes and micro-organisms distribution, these parameters should be more cautiously taken into account in multi-disciplinary studies.

\section{Acknowledgement}

Meteorological data and main channel stage were obtained from the Brazilian National Water Agency (http://hidroweb.ana.gov.br/) and the Brazilian national meteorological institute (www.inmet.gov.br/). Remotely sensed product can be freely assessed i) at the Alaska Satellite Facility website (https://vertex.daac.asf.alaska.edu/) for the ALOS-1/PALSAR images, ii) at the Center for Topographic studies of the Ocean and Hydrosphere (http://ctoh.legos.obsmip.fr/) website for the altimetry data. The processed data used in this work, including observations of floodplain stage, channel velocity exchanges and bathymetry data can be accessed through the following link http://dx.doi.org/10.17632/hvvpbnt8r3.1

This research was done under the auspices of CNPq (Conselho Nacional de Desenvolvimento Científico e Tecnológico, Brazil) and IRD (Institut de Recherche pour le Developpement, France) $n^{\circ}$ 490634/2013-3, and LMI OCE (Laboratoire Mixte International Observatoire des Changements Environementaux). Several research programs supported it: 
(CNES/TOSCA), (OSCA-Varz) CNPq-MCTI 400029/2015-4, INCT ODISSEIA (Grant n 162014 with funding from CNPq/CAPES/FAP-DF) and from the European Union Horizon 2020 Research and innovation program under the Marie Skłodowska - Curie grant agreement No. 691053 (H2020-MSCA-RISE-2015 ODYSSEA project). The first author is grateful to CAPES (Coordenação de Aperfeiçoamento de Pessoal de Nível Superior) in Brazil for financial support in the framework of the BIODIVA project from the Guyamazon program funded by FAPEAM/IRD/French Embassy. The authors declare that there is no conflict of interest.

\section{References}

Abril, G., Martinez, J. M., Artigas, L. F., Moreira-Turcq, P., Benedetti, M. F., Vidal, L., et al. (2014). Amazon River carbon dioxide outgassing fuelled by wetlands. Nature, 505(7483), 395-398. https://doi.org/10.1038/nature12797

Alsdorf, D. E., Rodriguez, E., \& Lettenmaier, D. P. (2007). Measuring surface water from space. Reviews of Geophysics, 45(2), 1-24. https://doi.org/10.1029/2006RG000197.1.INTRODUCTION

Amaral, J. H. F., Borges, A. V., Melack, J. M., Sarmento, H., Barbosa, P. M., Kasper, D., et al. (2018). Influence of plankton metabolism and mixing depth on CO2dynamics in an Amazon floodplain lake. Science of the Total Environment, 630, 1381-1393. https://doi.org/10.1016/j.scitotenv.2018.02.331

Anderson, E. P., Jenkins, C. N., Heilpern, S., Maldonado-Ocampo, J. A., Carvajal-Vallejos, F. M., Encalada, A. C., et al. (2018). Fragmentation of Andes-to-Amazon connectivity by hydropower dams. Science Advances, 4(1), 1-8. https://doi.org/10.1126/sciadv.aao1642

Arcement Jr, G. J., \& Schneider, V. R. (1989). Guide for Selecting Manning's Roughness Coefficients for Natural Channels and Flood Plains. Technical Report, Geological Survey Water-Supply, United States Government Printing Office, Washington, U.S.A, 38. https://doi.org/Report No. FHWA-TS-84-204

Arnesen, A. S., Silva, T. S. F. F., Hess, L., Novo, E. M. L. M., Rudorff, C. M., Chapron, B., et al. (2013). Monitoring flood extent in the lower Amazon River floodplain using ALOS/PALSAR ScanSAR images. Remote Sensing of Environment, 130, 51-61. https://doi.org/10.1016/j.rse.2012.10.035

Assis, R. L., Wittmann, F., Piedade, M. T. F., \& Haugaasen, T. (2014). Effects of hydroperiod and substrate properties on tree alpha diversity and composition in Amazonian floodplain forests. Plant Ecology, 216(1), 41-54. https://doi.org/10.1007/s11258-014-0415-y

B.R., F., J.M., M., T., D., R.B., B., M., G., R.C.D., P., et al. (2017). The potential impact of new Andean dams on Amazon fluvial ecosystems. PLoS ONE, 12(8), e0182254. https://doi.org/http://dx.doi.org/10.1371/journal.pone.0182254

Bates, P., \& De Roo, a. P. . (2000). A simple raster-based model for flood inundation simulation. Journal of Hydrology, 236(1-2), 54-77. https://doi.org/10.1016/S00221694(00)00278-X

Bates, P., Horritt, M. S., \& Fewtrell, T. J. (2010). A simple inertial formulation of the shallow water equations for efficient two-dimensional flood inundation modelling. Journal of Hydrology, 387(1-2), 33-45. https://doi.org/10.1016/j.jhydrol.2010.03.027

Baugh, C., Bates, P., Schumann, G., \& Trigg, M. (2013). SRTM vegetation removal and hydrodynamic modeling accuracy. Water Resources Research, 49(9), 5276-5289. https://doi.org/10.1002/wrcr.20412

Biancamaria, S., Frappart, F., Leleu, A. S., Marieu, V., Blumstein, D., Desjonquères, J. D., et al. (2017). Satellite radar altimetry water elevations performance over a $200 \mathrm{~m}$ wide river: Evaluation over the Garonne River. Advances in Space Research, 59(1), 128-146. https://doi.org/10.1016/j.asr.2016.10.008

Bonnet, M. P., Barroux, G., Martinez, J. M., Seyler, F., Moreira-Turcq, P., Cochonneau, G., et 
al. (2008). Floodplain hydrology in an Amazon floodplain lake (Lago Grande de Curuaí). Journal of Hydrology, 349(1-2), 18-30. https://doi.org/10.1016/j.jhydrol.2007.10.055

Bonnet, M. P., Lamback, B., Boaventura, G. R., Oilveira, E., Seyler, F., Calmant, S., et al. (2011). Impact of the 2009 exceptional flood on the flood plain of the Solimões River. Conceptual and Modelling Studies of Integrated Groundwater, Surface Water, and Ecological Systems Proceedings of Symposium H01, 1(July), 1-7.

Bonnet, M. P., Pinel, S., Garnier, J., Bois, J., Resende Boaventura, G., Seyler, P., et al. (2017). Amazonian floodplain water balance based on modelling and analyses of hydrologic and electrical conductivity data. Hydrological Processes, 31(November), 1-38. https://doi.org/10.1002/hyp.11138

Bourgoin, L. M., Bonnet, M. P., Martinez, J. M., Kosuth, P., Cochonneau, G., Moreira-Turcq, P., et al. (2007). Temporal dynamics of water and sediment exchanges between the Curuaí floodplain and the Amazon River, Brazil. Journal of Hydrology, 335(1-2), 140-156. https://doi.org/10.1016/j.jhydrol.2006.11.023

Canadian Hydraulics Centre. (2012). Blue Kenue. Retrieved September 1, 2018, from http://www.nrc-cnrc.gc.ca/eng/ibp/chc/software/kenue/bluekenue.html

Carabajal, C., \& Harding, D. (2006). SRTM C-Band and ICEsat Laser Altimetry Elevation Comparisons as a Function of Tree Cover and Relief. Photogrammetric Engineering \& Remote Sensing, 72(3), 287-298. https://doi.org/10.14358/PERS.72.3.287

Castello, L., \& Macedo, M. N. (2016). Large-scale degradation of Amazonian freshwater ecosystems. Global Change Biology, 22(3), 990-1007. https://doi.org/10.1111/gcb.13173

Castello, L., Mcgrath, D. G., Hess, L., Coe, M. T., Lefebvre, P., Petry, P., et al. (2013). The vulnerability of Amazon freshwater ecosystems. Conservation Letters.

Castello, L., Hess, L., Thapa, R., McGrath, D. G., Arantes, C. C., Renó, V. F., \& Isaac, V. J. (2018). Fishery yields vary with land cover on the Amazon River floodplain. Fish and Fisheries, 19(3), 431-440. https://doi.org/10.1111/faf.12261

Cobby, D. M., Mason, D. C., Horritt, M. S., \& Bates, P. (2003). Two-dimensional hydraulic flood modelling using a finite-element mesh decomposed according to vegetation and topographic features derived from airborne scanning laser altimetry. Hydrological Processes, 17(10), 1979-2000. https://doi.org/10.1002/hyp.1201

Day, R. H., Williams, T. M., \& Swarzenski, C. M. (2007). Hydrology of tidal freshwater forested wetlands of the Southeastern United States. In Ecology of Tidal Freshwater Forested Wetlands of the Southeastern United States. https://doi.org/10.1007/978-14020-5095-4_2

ESA. (2007). ENVISAT RA2 / MWR Product Handbook. European Spatial Agency.

Fassoni-Andrade, A. C., \& Paiva, R. C. D. de. (2019). Mapping spatial-temporal sediment dynamics of river-floodplains in the Amazon. Remote Sensing of Environment, 221, 94107. https://doi.org/10.1016/j.rse.2018.10.038

Ferreira-Ferreira, J., Silva, T. S. F., Streher, A. S., Affonso, A. G., De Almeida Furtado, L. F., Forsberg, B. R., et al. (2014). Combining ALOS/PALSAR derived vegetation structure and inundation patterns to characterize major vegetation types in the Mamirauá Sustainable Development Reserve, Central Amazon floodplain, Brazil. Wetlands Ecology and Management, 41-59. https://doi.org/10.1007/s11273-014-9359-1

Ferreira, J., Aragão, L. E. O. C., Barlow, J., Barreto, P., Berenguer, E., Bustamante, M., et al. (2014). Brazil's environmental leadership at risk: Mining and dams threaten protected areas. Science. https://doi.org/10.1126/science.1260194

Finer, M., \& Jenkins, C. N. (2012). Proliferation of hydroelectric dams in the andean amazon and implications for andes-amazon connectivity. PLoS ONE, 7(4). https://doi.org/10.1371/journal.pone.0035126

Frappart, F., Seyler, F., Martinez, J. M., León, J. G., \& Cazenave, a. (2005). Floodplain water 
storage in the Negro River basin estimated from microwave remote sensing of inundation area and water levels. Remote Sensing of Environment, 99, 387-399. https://doi.org/10.1016/j.rse.2005.08.016

Frias, C. E., Abad, J. D., Mendoza, A., Paredes, J., Ortals, C., \& Montoro, H. (2015). Planform evolution of two anabranching structures in the Upper Peruvian Amazon River. Water Resources Research, 51(4), 2742-2759. https://doi.org/10.1002/2014WR015836

Groenendijk, J., Duplaix, N., Marmontel, M., Van Damme, P., \& Schenck, C. (2015). Pteronura brasiliensis. The IUCN Red List of Threatened Species 2015: e.T18711A21938411. https://doi.org/http://dx.doi.org/10.2305/IUCN.UK.20152.RLTS.T18711A21938411.en.

Gurnell, A., \& Petts, G. (2010). Hydrology and Ecology of River Systems. In Treatise on Water Science (Vol. 2, pp. 237-269). https://doi.org/10.1016/B978-0-444-53199-5.00037-3

Hernandez, W. J., \& Armstrong, R. A. (2016). Deriving bathymetry from multispectral remote sensing data. Journal of Marine Science and Engineering, 4(1). https://doi.org/10.3390/jmse4010008

Hervouet, J. M. (2000). TELEMAC modelling system: an overview. Hydrological Processes, 14(13), 2209-2210. https://doi.org/10.1002/1099-1085(200009)14:13<2209::AIDHYP23>3.0.CO;2-6

Hess, L., \& Stiefel, E. (1952). Methods of Conjugate Gradients for Solving Linear Systems. Journal of Research of the National Bureau of Standards. https://doi.org/10.6028/jres.049.044

Hess, L., Melack, J. M., Novo, E. M. L. M., Barbosa, C. C. F., \& Gastil-Buhl, M. (2003). Dualseason mapping of wetland inundation and vegetation for the central Amazon basin. $\begin{array}{llll}\text { Remote Sensing of Environment, } & \text { 87(4), }\end{array}$ https://doi.org/10.1016/j.rse.2003.04.001

Hess, L., Melack, J. M., Affonso, A. G., Barbosa, C., Gastil-Buhl, M., \& Novo, E. M. L. M. (2015). Wetlands of the Lowland Amazon Basin: Extent, Vegetative Cover, and Dualseason Inundated Area as Mapped with JERS-1 Synthetic Aperture Radar. Wetlands, 35(4), 745-756. https://doi.org/10.1007/s13157-015-0666-y

Hjulstrom, F. (1939). Transportation of Detritus by Moving Water: Part 1. Transportation. Recent Marine Sediments.

Hostache, R., Hissler, C., Matgen, P., Guignard, C., \& Bates, P. (2014). Modelling suspendedsediment propagation and related heavy metal contamination in floodplains: A parameter sensitivity analysis. Hydrology and Earth System Sciences, 18(9), 3539-3551. https://doi.org/10.5194/hess-18-3539-2014

Ji, X., Lesack, L. F. W., Melack, J. M., Wang, S., Riley, W. J., \& Shen, C. (2019). Seasonal and Interannual Patterns and Controls of Hydrological Fluxes in an Amazon Floodplain Lake With a Surface-Subsurface Process Model. Water Resources Research, 55(4), 30563075. https://doi.org/10.1029/2018WR023897

Lang, P., Desombre, J., \& Ata, R. (2014). TELEMAC-2D Software Release 7.0 User Manual.

Latrubesse, E. M. M., Arima, E. Y., Dunne, T., Park, E., Baker, V. R., D’Horta, F. M., et al. (2017). Damming the rivers of the Amazon basin. Nature. https://doi.org/10.1038/nature22333

Lesack, L. F. W., \& Melack, J. M. (1995). Flooding hydrology and mixture dynamics of lake water derived from multiple sources in an Amazon f.pdf. Water Resources Research.

Luo, X., Li, H. Y., Ruby Leung, L., Tesfa, T. K., Getirana, A., Papa, F., \& Hess, L. (2017). Modeling surface water dynamics in the Amazon Basin using MOSART-Inundation v1.0: Impacts of geomorphological parameters and river flow representation. Geoscientific Model Development, 10(3), 1233-1259. https://doi.org/10.5194/gmd-10-1233-2017

Maillard, P., Bercher, N., \& Calmant, S. (2015). New processing approaches on the retrieval 
of water levels in Envisat and SARAL radar altimetry over rivers: A case study of the Sao Francisco River, Brazil. Remote Sensing of Environment, 156, 226-241. https://doi.org/10.1016/j.rse.2014.09.027

Mangiarotti, S., Martinez, J. M., Bonnet, M. P., Buarque, D. C., Filizola, N., \& Mazzega, P. (2013). Discharge and suspended sediment flux estimated along the mainstream of the Amazon and the Madeira Rivers (from in situ and MODIS Satellite Data). International Journal of Applied Earth Observation and Geoinformation, 21, 341-355. https://doi.org/10.1016/j.jag.2012.07.015

Martinez, J. M., \& Le Toan, T. (2007). Mapping of flood dynamics and spatial distribution of vegetation in the Amazon floodplain using multitemporal SAR data. Remote Sensing of Environment, 108(3), 209-223. https://doi.org/10.1016/j.rse.2006.11.012

Melack, J. M., Hess, L., Gastil-Buhl, M., Forsberg, B. R., Hamilton, S. K., Lima, I. B. T., \& Novo, E. M. L. M. (2004). Regionalization of methane emissions in the Amazon Basin with microwave remote sensing. Global Change Biology, 10(5), 530-544.

Mendoza, A., Abad, J. D., Frias, C. E., Ortals, C., Paredes, J., Montoro, H., et al. (2016). Planform dynamics of the Iquitos anabranching structure in the Peruvian Upper Amazon River. Earth Surface Processes and Landforms, 41(7), 961-970. https://doi.org/10.1002/esp.3911

Mertes, L. (1997a). Documentation and significance of the perirheic zone on inundated floodplains. Water Resources Research, 33(7), 1749-1762. https://doi.org/10.1029/97WR00658

Mertes, L. (1997b). Documentation and significance of the perirheic zone on inundated $\begin{array}{lllll}\text { floodplains. Water } & \text { Resources }\end{array}$ https://doi.org/10.1029/97WR00658

Moreira-Turcq, P., Bonnet, M. P., Amouroux, D., Bernardes, M. C., Lagane, C., MauriceBourgoin, L., et al. (2013). Seasonal variability in concentration, composition, age, and fluxes of particulate organic carbon exchanged between the floodplain and Amazon River. Global Biogeochemical Cycles, 27(1), 119-130. https://doi.org/10.1002/gbc.20022

Moulinec, C., Denis, C., Pham, C. T., Rougé, D., Hervouet, J. M., Razafindrakoto, E., et al. (2011). TELEMAC: An efficient hydrodynamics suite for massively parallel architectures. Computers and Fluids, 51(1), 30-34. https://doi.org/10.1016/j.compfluid.2011.07.003

$\mathrm{Mu}, \mathrm{L}$. (2009). Thiessen Polygon. In International Encyclopedia of Human Geography (pp. 231-236). https://doi.org/10.1016/b978-008044910-4.00545-9

Nash, J. E., \& Sutcliffe, J. V. (1970). River flow forecasting through conceptual models part I A discussion of principles. Journal of Hydrology, 10(3), 282-290. https://doi.org/10.1016/0022-1694(70)90255-6

Oliveros, C., Idier, D., \& Dewez, T. (2008). Etude des possibilites de rechargement des plages de Cayenne.

Paiva, R. C. D., Collischonn, W., \& Buarque, D. C. (2011). Validation of a full hydrodynamic model for large-scale hydrologic modelling in the Amazon. Hydrological Processes, 27(3), 333-346. https://doi.org/10.1002/hyp

Paiva, R. C. D., Buarque, D. C., Collischonn, W., Bonnet, M. P., Frappart, F., Calmant, S., \& Bulhões Mendes, C. A. (2013). Large-scale hydrologic and hydrodynamic modeling of the Amazon River basin. Water Resources Research, 49(3), 1226-1243. https://doi.org/10.1002/wrcr.20067

Park, E., \& Latrubesse, E. M. M. (2017). The hydro-geomorphologic complexity of the lower Amazon River floodplain and hydrological connectivity assessed by remote sensing and field control. Remote Sensing of Environment, 198, 321-332. https://doi.org/10.1016/j.rse.2017.06.021 
Pekel, J.-F., Cottam, A., Gorelick, N., \& Belward, A. S. (2016). High-resolution mapping of global surface water and its long-term changes. Nature. https://doi.org/10.1038/nature20584

Pinel, S., Bonnet, M. P., Santos, J., Moreira, D., Calmant, S., Satge, F., \& Seyler, F. (2015). Correction of interferometric and vegetation biases in the SRTMGL1 spaceborne DEM with hydrological conditioning towards improved hydrodynamics modeling in the Amazon basin. Remote Sensing, 16108-16130. https://doi.org/10.3390/rs70x000x

Richey, J. E., Mertes, L., Dunne, T., Victoria, R. L., Forsberg, B. R., Tancredi, A. C. F. N. S., \& Oliveira, E. (1989). Sources and routing of the Amazon River flood wave. Global Biogeochemical Cycles, 3(3), 191-204. https://doi.org/10.1029/GB003i003p00191

Rodriguez, E., Morris, C. C., \& Belz, J. J. (2006). A global assessment of the SRTM performance. Photogrammetric Engineering and Remote Sensing, 72(3), 249-260. Retrieved from http://www.asprs.org/a/publications/pers/2006journal/march/2006_mar_249-260.pdf

Rosales, J., Blanco-Belmonte, L., \& Bradley, C. (2008). Hydrogeomorphological and Ecological Interactions in Tropical Floodplains: The Significance of Confluence Zones in the Orinoco Basin, Venezuela. In Hydroecology and Ecohydrology: Past, Present and Future (pp. 295-316). https://doi.org/10.1002/9780470010198.ch16

Rosenqvist, A., Shimada, M., Lucas, R., Chapman, B., Paillou, P., Hess, L., \& Lowry, J. (2010). The Kyoto \&amp; Carbon Initiative - A Brief Summary. IEEE Journal of Selected Topics in Applied Earth Observations and Remote Sensing, 3(4), 551-553. https://doi.org/10.1109/JSTARS.2010.2086270

Roux, E., Santos, J., Cesar Vieira Getirana, A., Bonnet, M. P., Calmant, S., Martinez, J. M., et al. (2010). Producing time series of river water height by means of satellite radar altimetry-a comparative study. Hydrological Sciences Journal, 55(1), 104-120. https://doi.org/10.1080/02626660903529023

Rudorff, C. M., Melack, J. M., \& Bates, P. (2014a). Flooding dynamics on the lower Amazon floodplain: 1. Hydraulic controls on water elevation, inundation extent, and riverfloodplain discharge. Water Resources Research, 50(1), 619-634. https://doi.org/10.1002/2013WR014091

Rudorff, C. M., Melack, J. M., \& Bates, P. (2014b). Flooding dynamics on the lower Amazon floodplain: 2. Seasonal and interannual hydrological variability. Water Resources Research, 50(January), 635-649. https://doi.org/10.1002/2013WR014714

Rudorff, C. M., Dunne, T., \& Melack, J. M. (2018). Recent increase of river-floodplain suspended sediment exchange in a reach of the lower Amazon River. Earth Surface Processes and Landforms, 43(1), 322-332. https://doi.org/10.1002/esp.4247

Santos, J., Calmant, S., Seyler, F., Rotunno Filho, O. C., Cochonneau, G., \& Mansur, W. J. (2010). Water levels in the Amazon basin derived from the ERS 2 and ENVISAT radar altimetry missions. Remote Sensing of Environment, 114(10), 2160-2181. https://doi.org/10.1016/j.rse.2010.04.020

Silva, B. M. da S. e, Lima, J. D., Dantas, V. A. V., Moraes, W. da S., \& Sabonaro, D. Z. (2007). Efeito da luz no crescimento de mudas de Hymenaea parvifolia Huber. Revista Árvore, 31(6), 1019-1026. https://doi.org/10.1590/S0100-67622007000600006

Silva, J. S. Da, Seyler, F., Calmant, S., Rotunno Filho, O. C., Roux, E., Araújo, A. A. M., \& Guyot, J. L. (2012). Water level dynamics of Amazon wetlands at the watershed scale by satellite altimetry. International Journal of Remote Sensing.

Da Silva, V., Trujillo, F., Martin, A., Zerbini, A. N., Crespo, E., Aliaga-Rossel, E., \& Reeves, R. (2018). 2018.Inia geoffrensis. The IUCN Red List of Threatened Species 2018: e.T10831A50358152. Retrieved from http://dx.doi.org/10.2305/IUCN.UK.20182.RLTS.T10831A50358152.en 
Sioli, H. (1984). Limnology and landscape ecology of a mighty tropical river and its basin.

Smolders, S., Plancke, Y., Ides, S., Meire, P., \& Temmerman, S. (2015). Role of intertidal wetlands for tidal and storm tide attenuation along a confined estuary: A model study. Natural Hazards and Earth System Sciences, 15(7), 1659-1675. https://doi.org/10.5194/nhess-15-1659-2015

Teledyne RDI. (2013). Workhorse Rio Grande ADCP. Retrieved from http://www.rdinstruments.com/datasheets/rio_grande_ds_lr.pdf

Tockner, K., Bunn, S., Gordon, C., Naiman, J., Robert, P. Q., Gerry, A., \& Stanford, J. (2008). Flood plains: Critically threatened ecosystems Author Book Title Downloaded from Griffith Research Online Á Flood plains : critically threatened ecosystems. In N. Polunin (Ed.), Aquatic ecosystems. Trends and Global Prospects (Cambridge). Cambridge: Fondation for Environmental Conservation.

Tonina, D., \& Jorde, K. (2013). Hydraulic Modelling Approaches for Ecohydraulic Studies: 3D, 2D, 1D and Non-Numerical Models. In Ecohydraulics: An Integrated Approach. https://doi.org/10.1002/9781118526576.ch3

Trevethan, M., Santos, R. V., Ianniruberto, M., Oliveira, M., Martinelli, A., \& Gualtieri, C. (2016). Influence of tributary water chemistry on hydrodynamics and fish biogeography about the confluence of Negro and Solimões rivers, Brazil. $11^{\circ}$ Simpósio Internacional de Eco-Hidráulica (ISE 2016), (4), 16.

Trigg, M., Bates, P., Wilson, M. D., Schumann, G., \& Baugh, C. (2012). Floodplain channel morphology and networks of the middle Amazon River. Water Resources Research, 48(10), 1-17. https://doi.org/10.1029/2012WR011888

Verron, J., Sengenes, P., Lambin, J., Noubel, J., Steunou, N., Guillot, A., et al. (2015). The SARAL/AltiKa Altimetry Satellite Mission. Marine Geodesy, (February), 00-00. https://doi.org/10.1080/01490419.2014.1000471

Vu, T. T., Nguyen, P. K. T., Chua, L. H. C., \& Law, A. W. K. (2015). Two-Dimensional Hydrodynamic Modelling of Flood Inundation for a Part of the Mekong River with TELEMAC-2D. British Journal of Environment \& Climate ChangeBJECC, 5013(2), 162-175. https://doi.org/10.9734/BJECC/2015/12885

Wilson, M. D., Bates, P., Alsdorf, D. E., Forsberg, B. R., Horritt, M. S., Melack, J. M., et al. (2007). Modeling large-scale inundation of Amazonian seasonally flooded wetlands. Geophysical Research Letters, 34(15), L15404. https://doi.org/10.1029/2007GL030156

Wittmann, F., Schöngart, J., Montero, J. C., Motzer, T., Junk, W., Piedade, M. T. F., et al. (2006). Tree species composition and diversity gradients in white-water forests across the Amazon Basin. Journal of Biogeography, 33, 1334-1347. https://doi.org/10.1111/j.13652699.2006.01495.x

Yamazaki, D., Kanae, S., Kim, H., \& Oki, T. (2011). A physically based description of floodplain inundation dynamics in a global river routing model. Water Resources Research, 47(4), n/a-n/a. https://doi.org/10.1029/2010WR009726

Yamazaki, D., Baugh, C., Bates, P., Kanae, S., Alsdorf, D. E., \& Oki, T. (2012). Adjustment of a spaceborne DEM for use in floodplain hydrodynamic modeling. Journal of Hydrology, 436-437, 81-91. https://doi.org/10.1016/j.jhydrol.2012.02.045 
Table 1. Characteristics of ALOS-1/PALSAR data used. Information from Rosenqvist et al. (2010)

\begin{tabular}{cccccc}
\hline Product type & Res.** & Pol.*** & IA**** & Swath & $\begin{array}{c}\text { Footprint } \\
\text { type }\end{array}$ \\
\hline $\begin{array}{c}\text { Fine beam single } \\
\text { (FBS) }\end{array}$ & 6.25 & $\mathrm{HH}$ & $34.3^{\circ}$ & $70 \mathrm{~km}$ & $\begin{array}{c}9 \text { images of } \\
\text { type } 1\end{array}$ \\
$\begin{array}{c}\text { Fine beam dual } \\
\text { (FBD) }\end{array}$ & 12.5 & $\mathrm{HH}, \mathrm{HV}$ & $34.3^{\circ}$ & $70 \mathrm{~km}$ & $\begin{array}{c}\text { images of } \\
\text { type } 1 \\
7 \text { images of } \\
\text { type } 2\end{array}$ \\
$\begin{array}{c}\text { Polarimetry mode } \\
\text { (PLR) }\end{array}$ & 30 & $\mathrm{HH}$ & $21.5^{\circ}$ & $30 \mathrm{~km}$ & $\begin{array}{c}3 \text { images of } \\
\text { type } 3\end{array}$ \\
\hline *Res. = Resolution $(\mathrm{m})$ & $* * \mathrm{Pol}=$ Polarization & $* * * \mathrm{IA}=$ Incidence angle at the scene center
\end{tabular}

Table 2. Results of horizontal accuracy for FE (flood extent) modelling

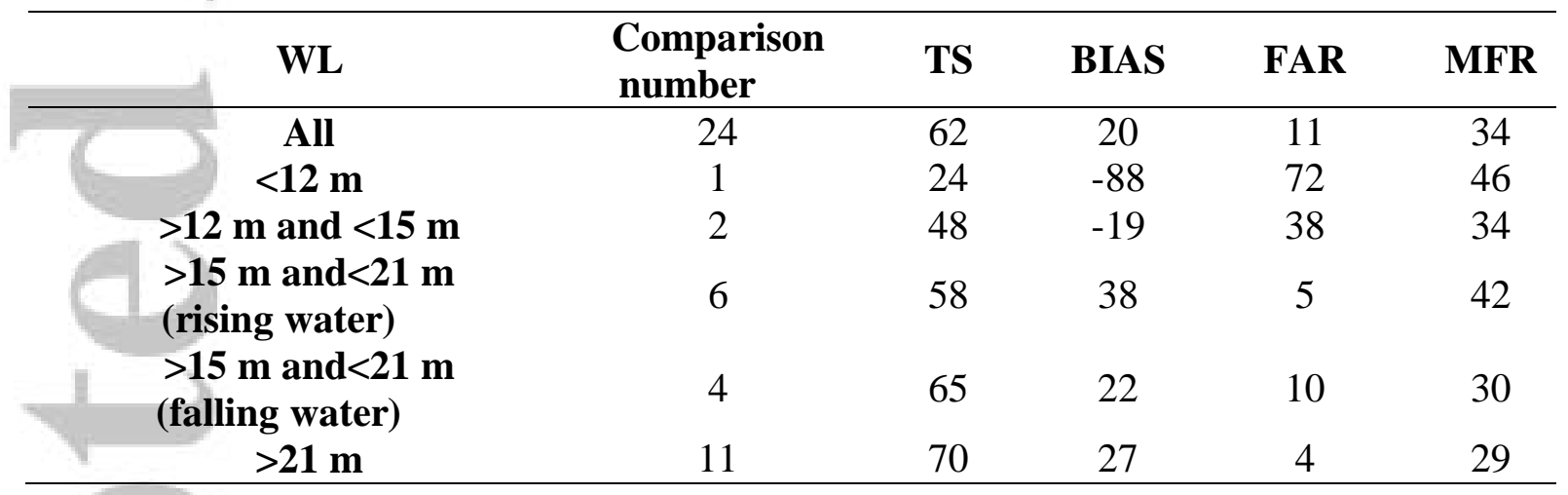


a)
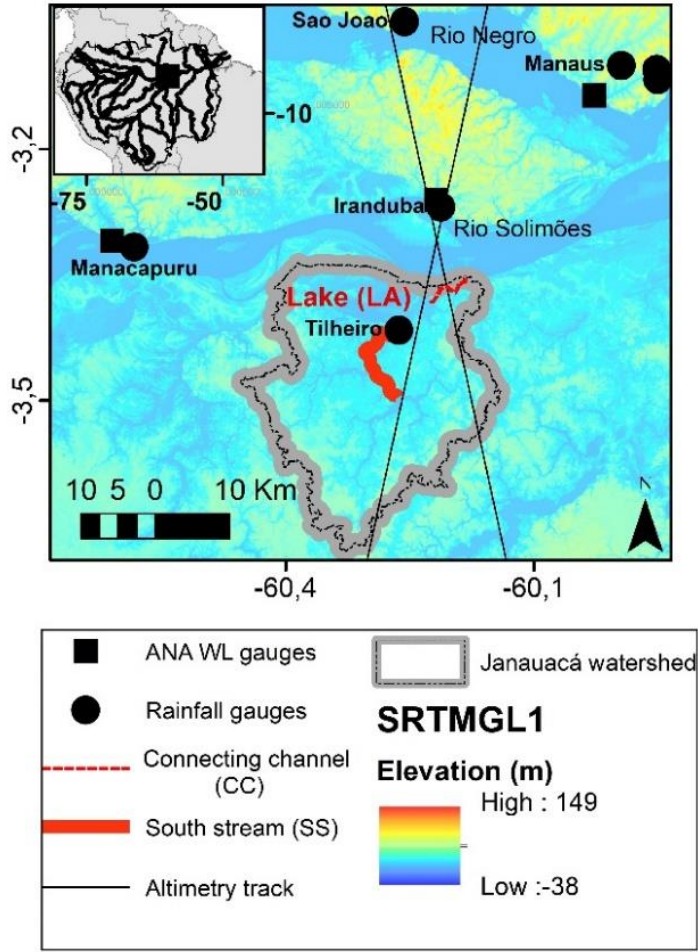

b)

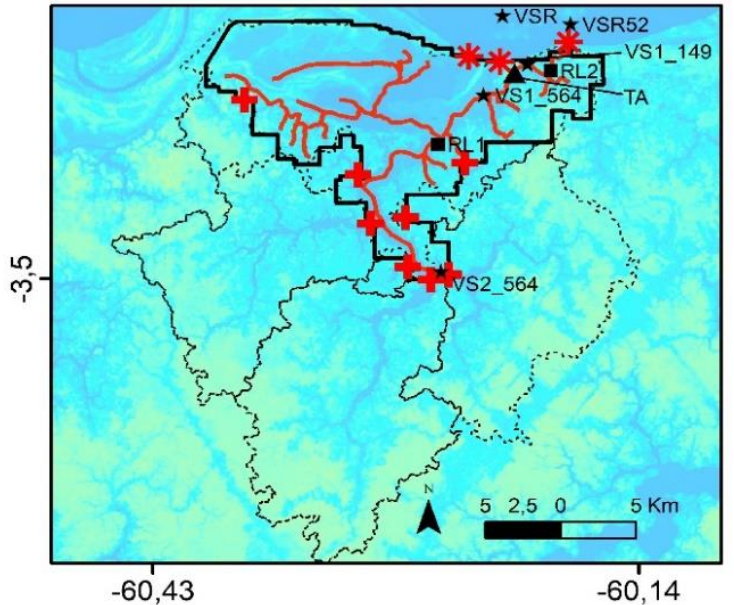

$\star \quad$ Virtual stations $\quad+\quad$ Local input

- Water level gauges Channels

- TA $\longrightarrow$ Modeled domain

* River input Watershed

Figure 1. a) Study site with the locations of available water level and rainfall gauges, b) Model domain with background SRTMGL1 and boundaries location 


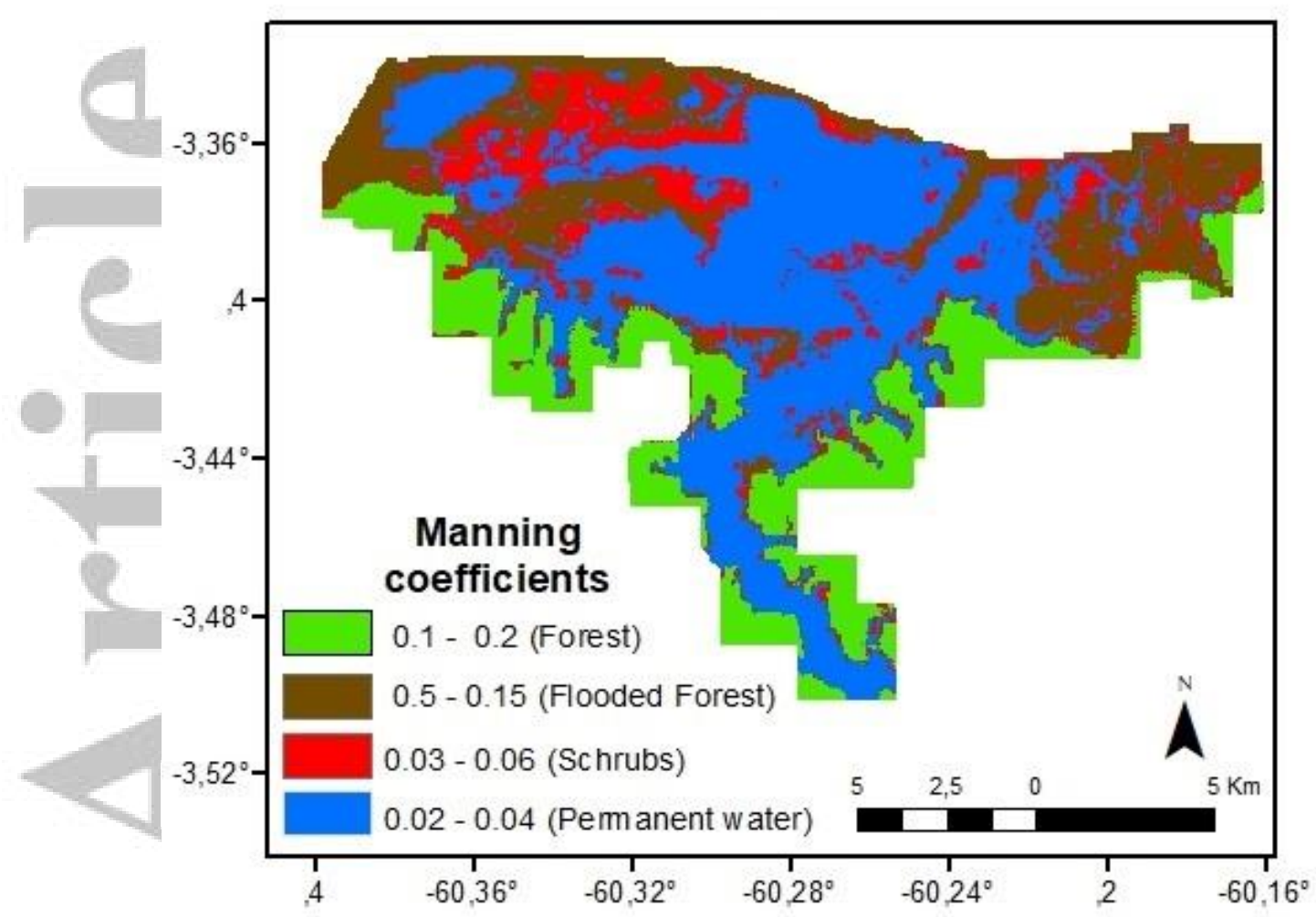

Figure 2. Manning coefficient values ranges of the modelled domain and their associated land cover type 
25 -

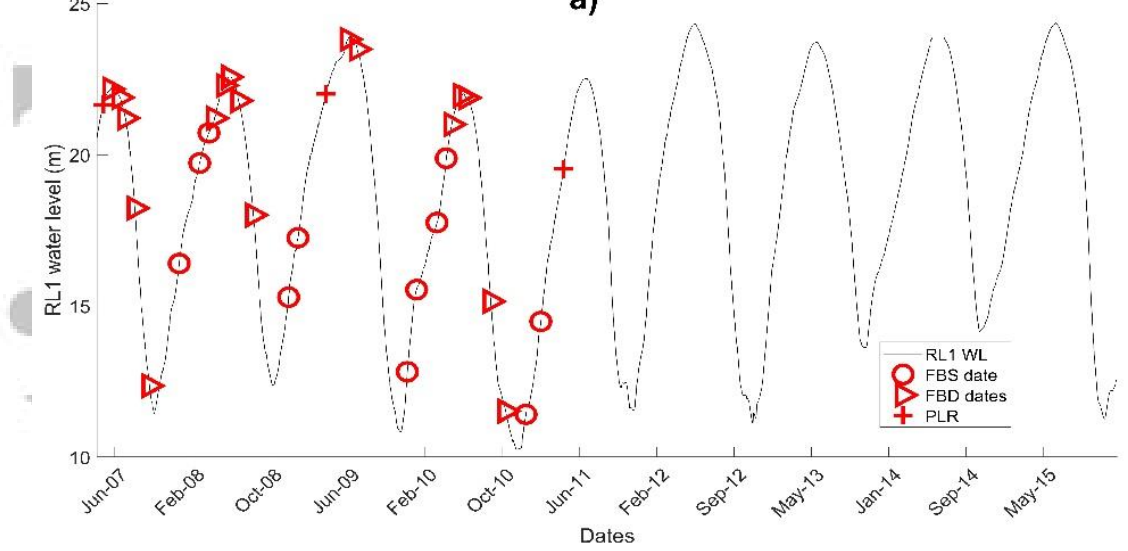

b)

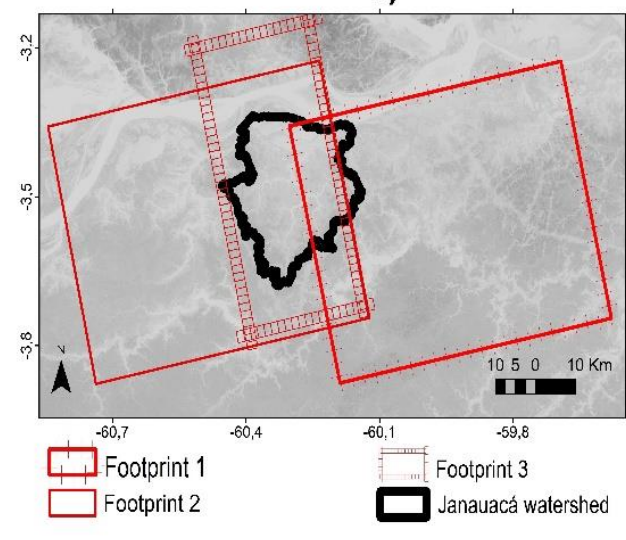

Figure 3. a) ALOS-1/PALSAR images availability following RL1 WL (RL1 water level), b) ALOS-1/PALSAR images footprints

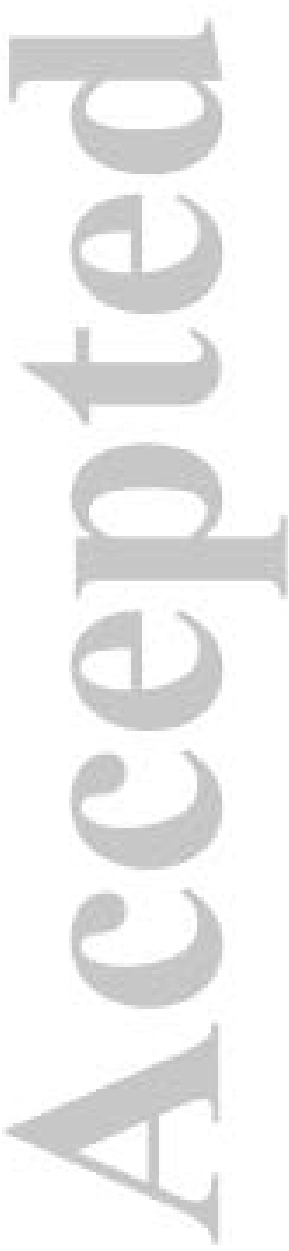



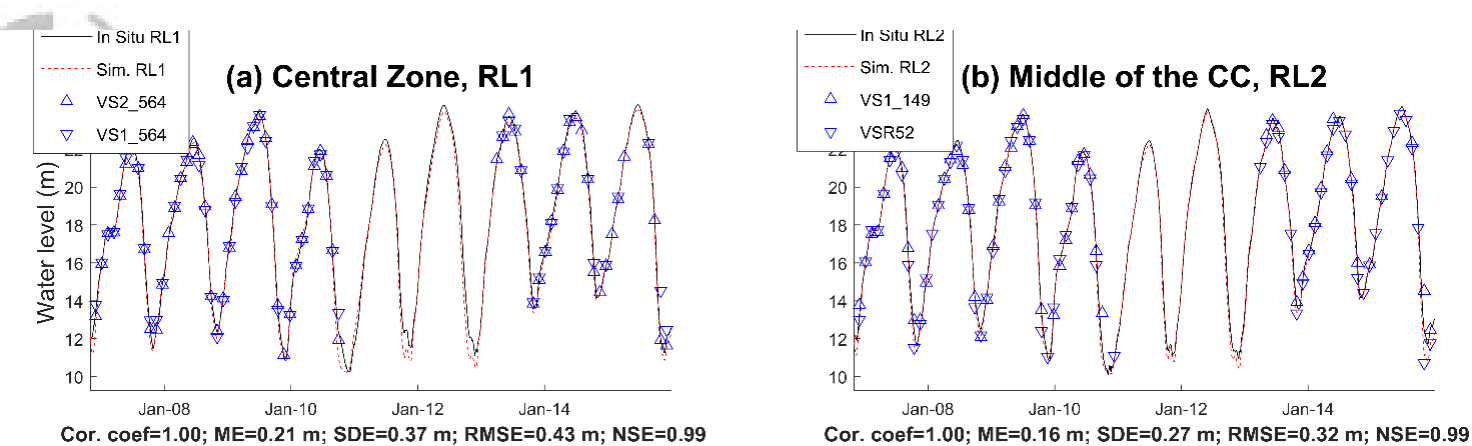

(c) Middle of the CC (2/2), VS1_149

(d) Central zone, VS1_564

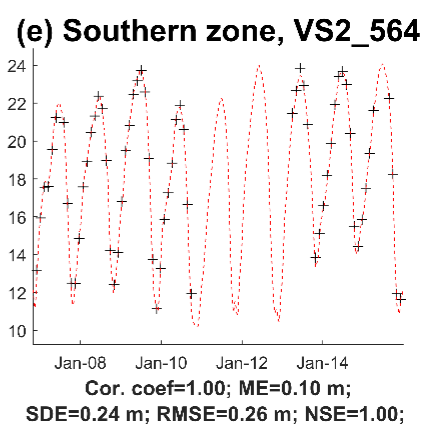

Figure 4. Comparison between simulated and observed water level at the 5 stations: RL1 (a), RL2 (b), at VS1_149 (c), VS1_564 (d) and VS2_564 (e). 
a) $W L<12 \mathrm{~m}$ 2010-12-25 (late low water)

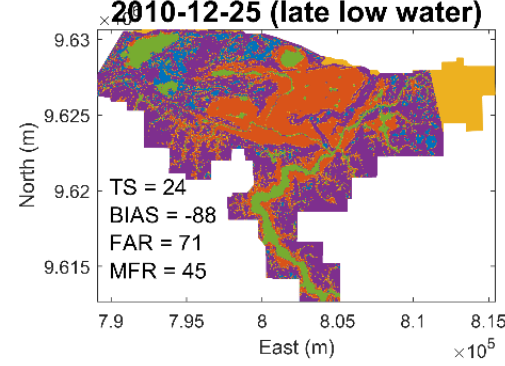

d) $>15 \mathrm{~m}$ and $<21 \mathrm{~m}$

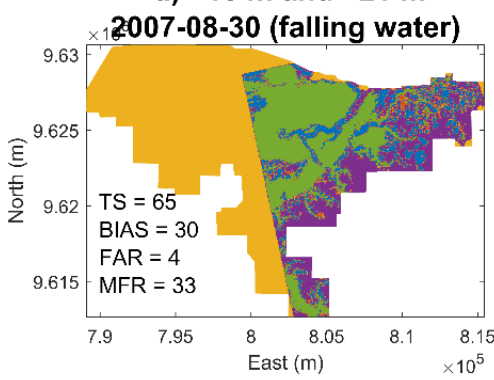

b) $>12 \mathrm{~m}$ and $<15 \mathrm{~m}$

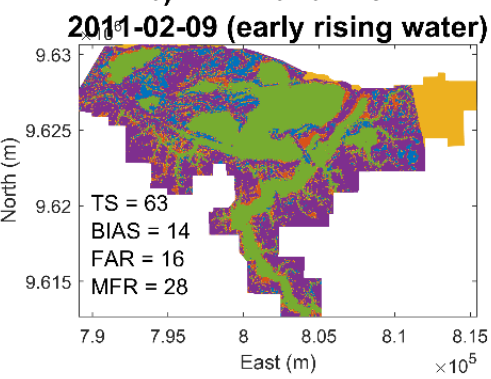

e) $>21 \mathrm{~m}$

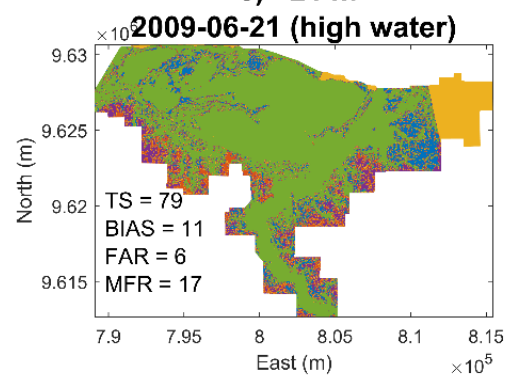

c) $>15 \mathrm{~m}$ and $<21 \mathrm{~m}$

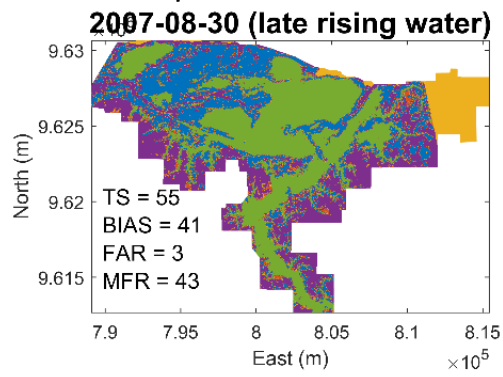

Flooded
Not flooded
No data
Over-prediction
Under-prediction

Figure 5. Comparisons of inundation extent obtained by TELEMAC-2D simulation against inundation maps for different periods a) WL $<12 \mathrm{~m}$ (low water), b) $12 \mathrm{~m} \mathrm{WL}<15$ $\mathrm{m}$ (early rising water), c) $15 \mathrm{~m}<\mathrm{WL}<21 \mathrm{~m}$ (late rising water) d) $15 \mathrm{~m}<\mathrm{WL}<21 \mathrm{~m}$ (falling water), e) WL $>21 \mathrm{~m}$ (high water) 
a) Time series of simulated and in situ TA velocities

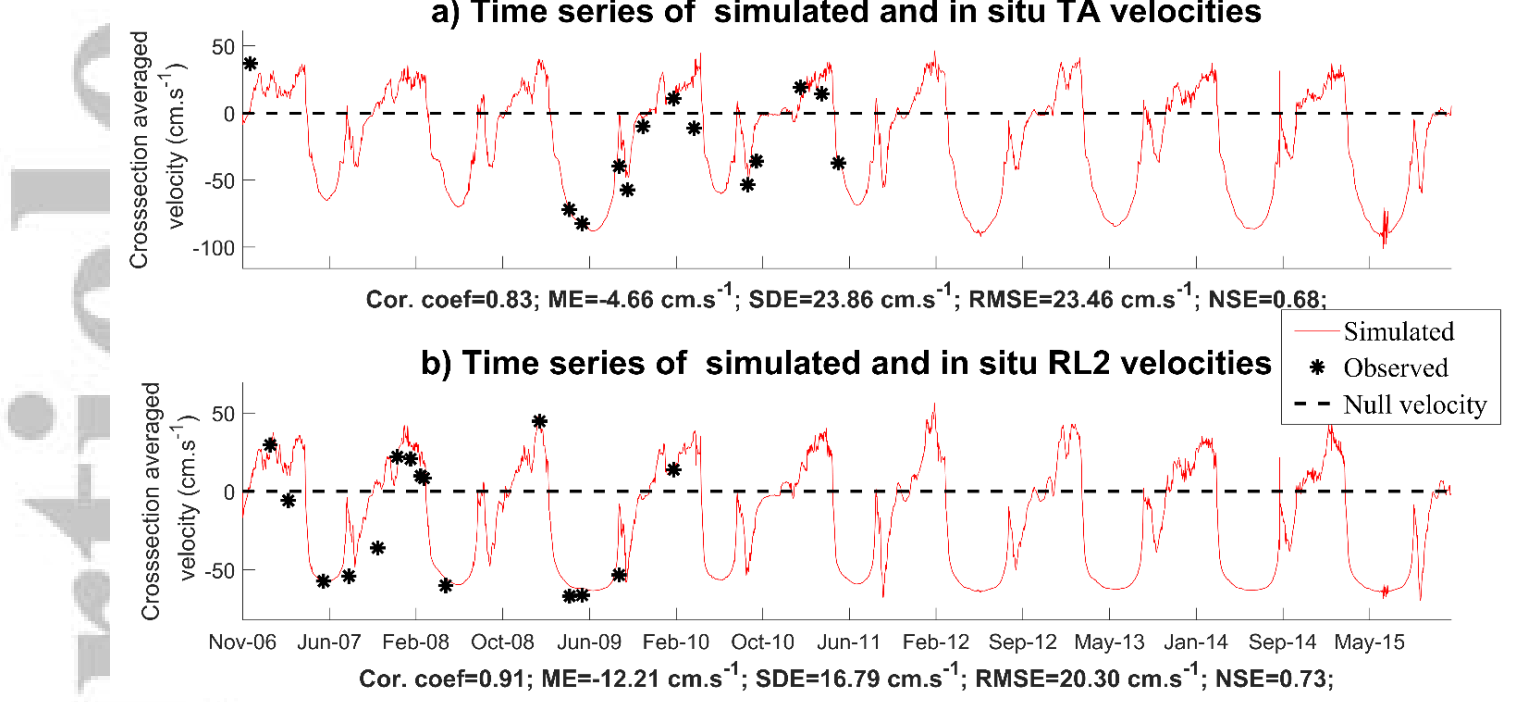

Figure 6. Velocity validation: location simulated and observed averaged velocities for cross-section a) at TA location, b) at RL2.

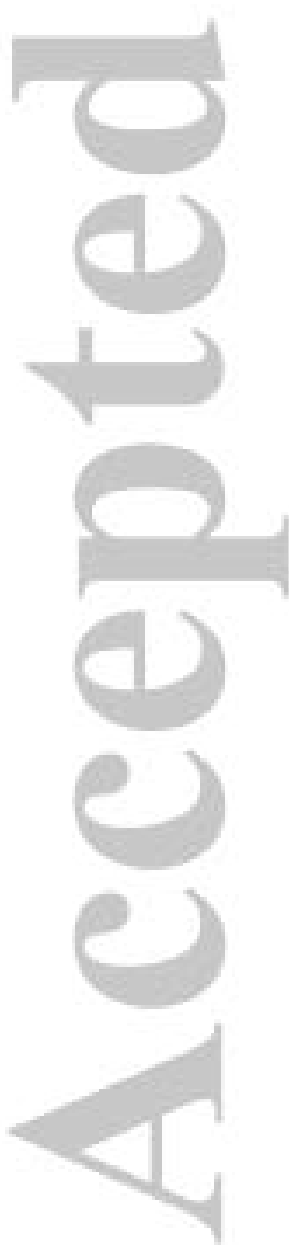




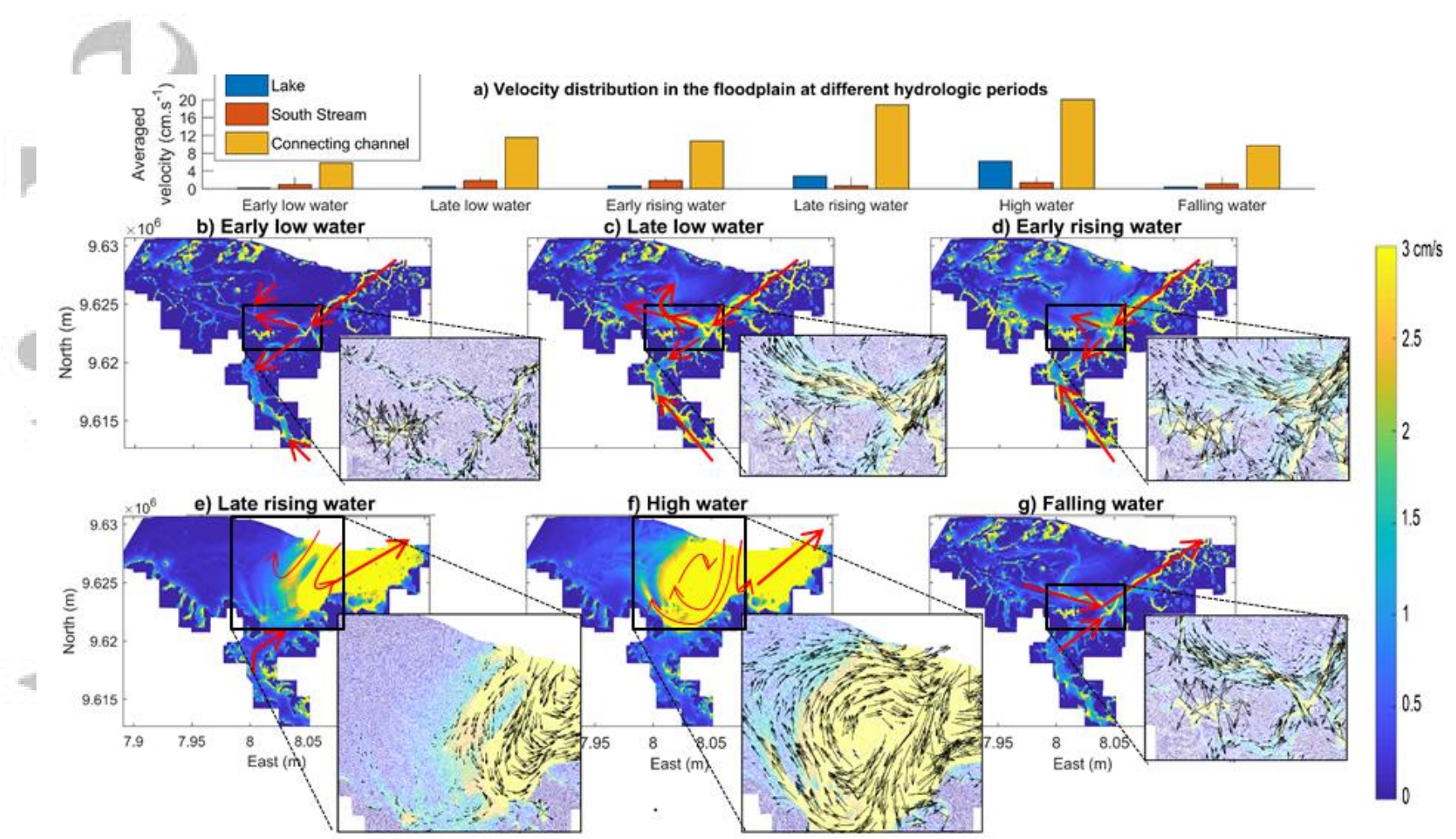

Figure 7. a) Average velocity distribution following the hydrologic period, b)-g) velocity distribution in the FP at different hydrological periods with velocity magnitude in $\mathrm{cm}^{-\mathrm{s}^{-1}}$ set as background. The schematic red and black arrows indicate the direction of water circulation. 


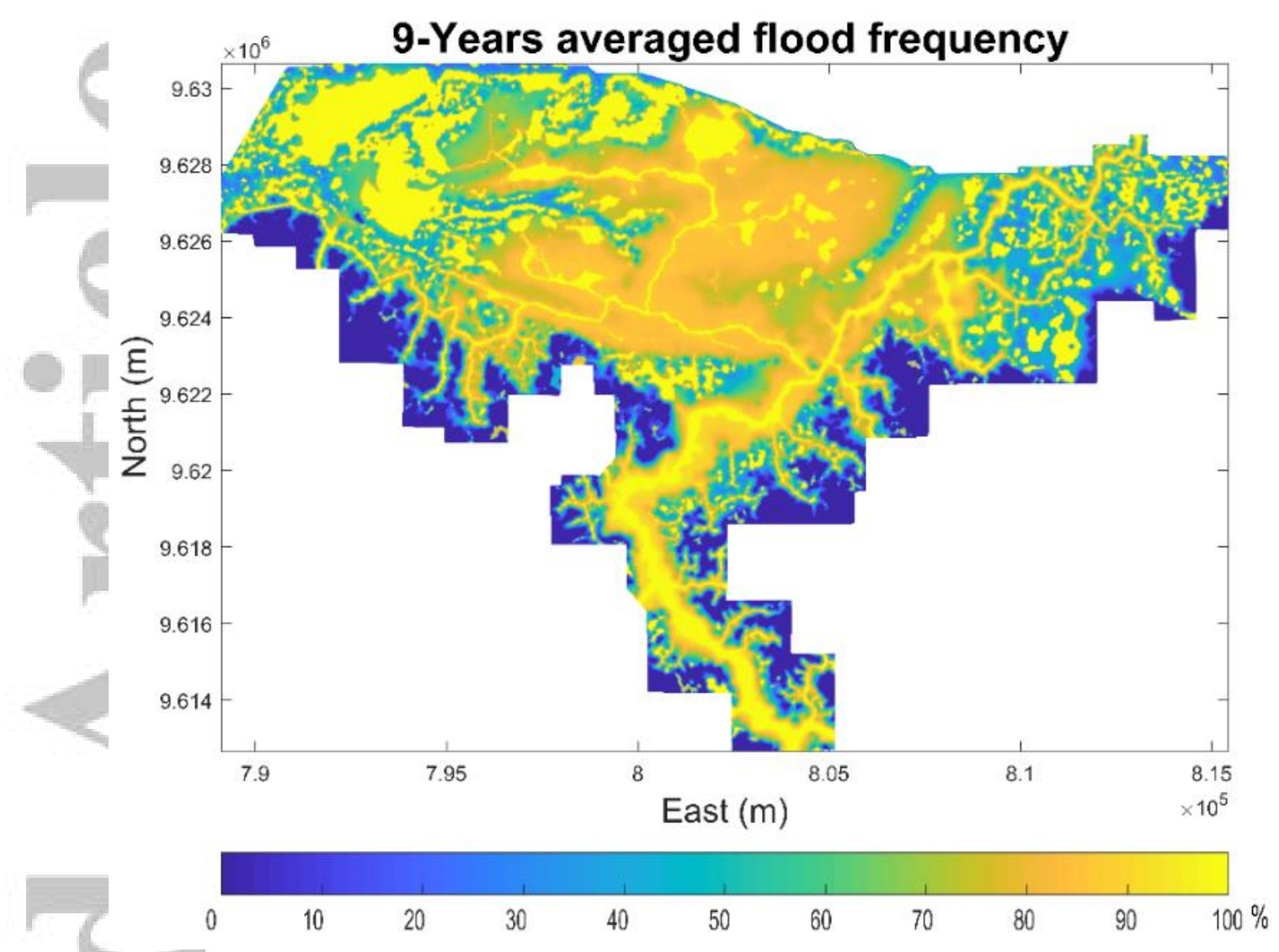

Figure 8. 9-years averaged frequency flood map. 


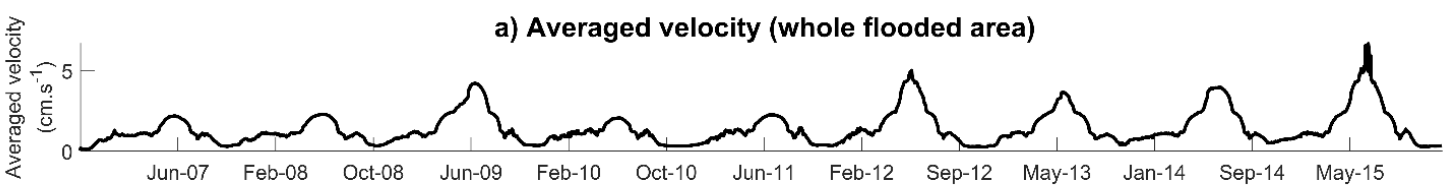

b) Averaged velocity in the connecting channel
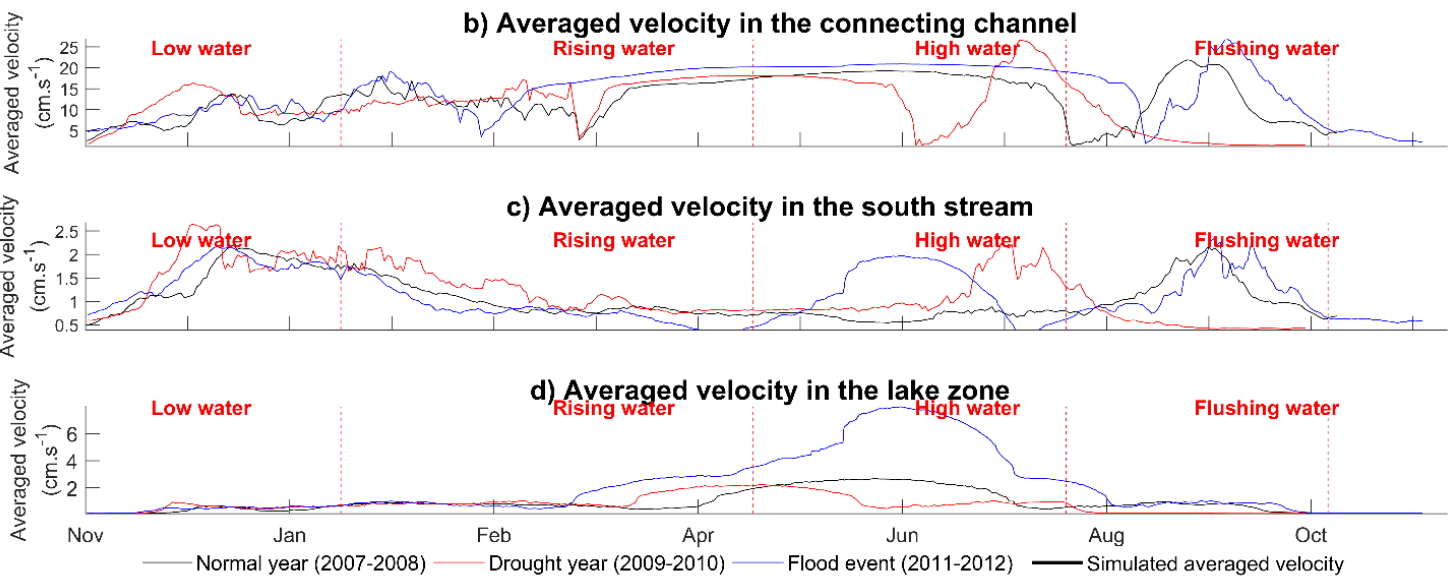

Figure 9. Time series of velocity magnitude averaged a) over the whole flooded area, b)d) by domain. In these plots, we also reported the average velocity magnitude obtained for 2009-2010 drought and 2011-2012 flood 

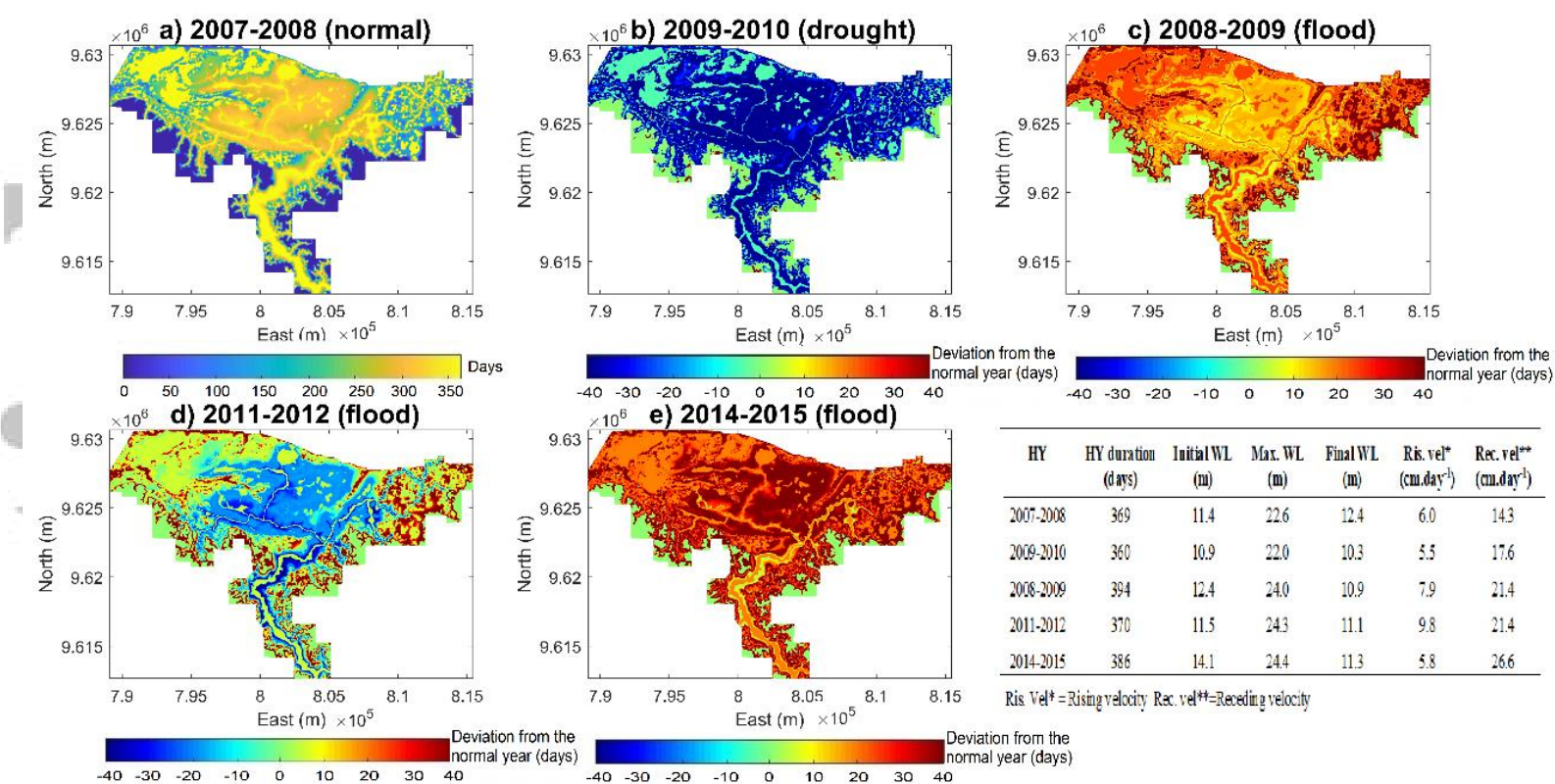

Figure 10. a) Spatial distribution of inundation duration for a hydrological normal year, deviations from the normal year b) a drought hydrological year, c-e) flood extreme events. The table indicates the HY characteristics (duration, minimum and maximum).

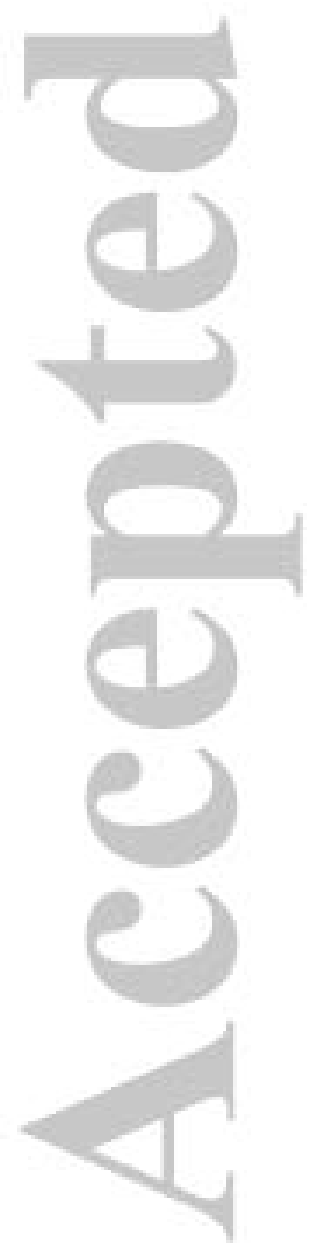




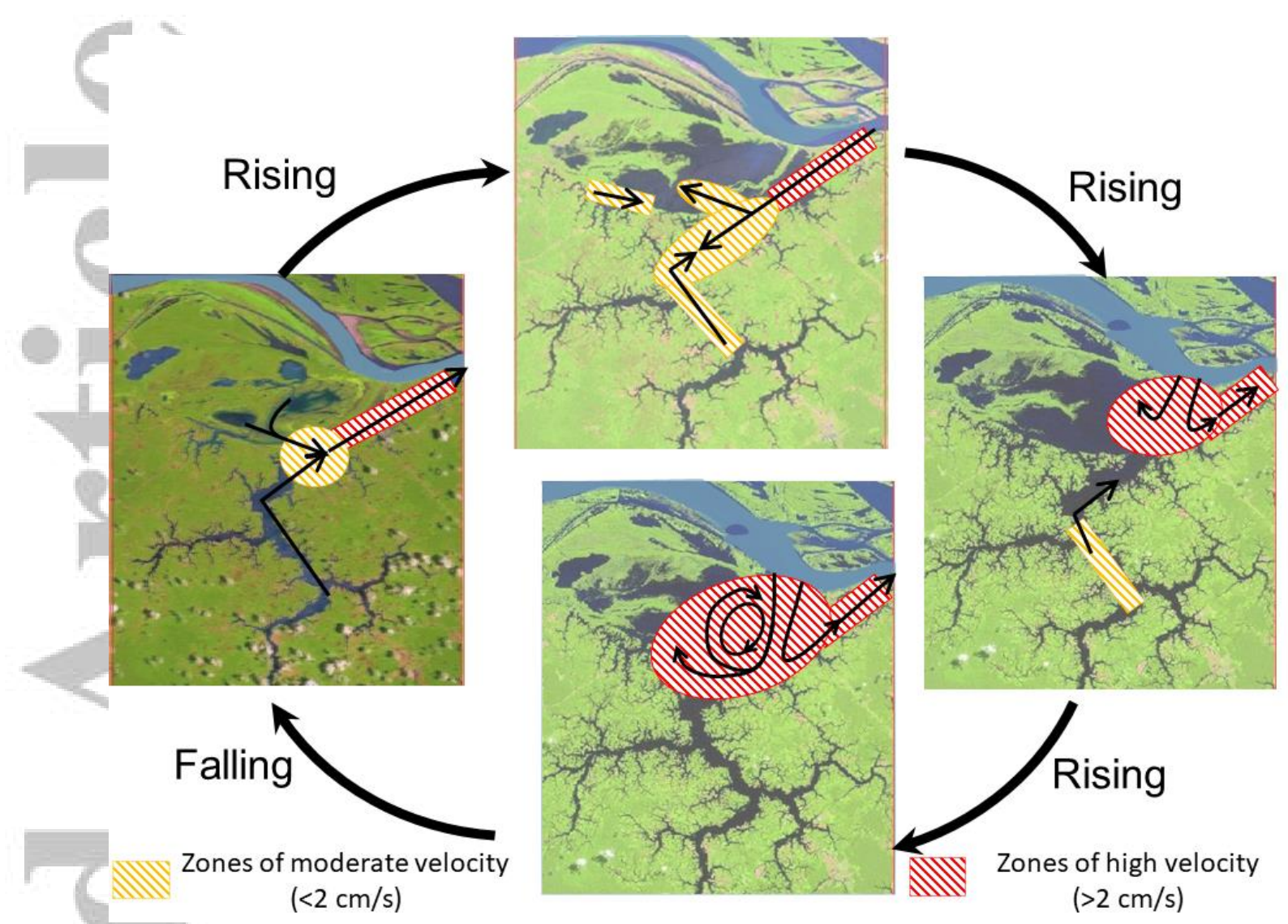

Figure 11. Conceptual velocity patterns over the Amazonian floodplain Janauacá along a hydrological year. The schematic black arrows indicate the direction of water circulation.

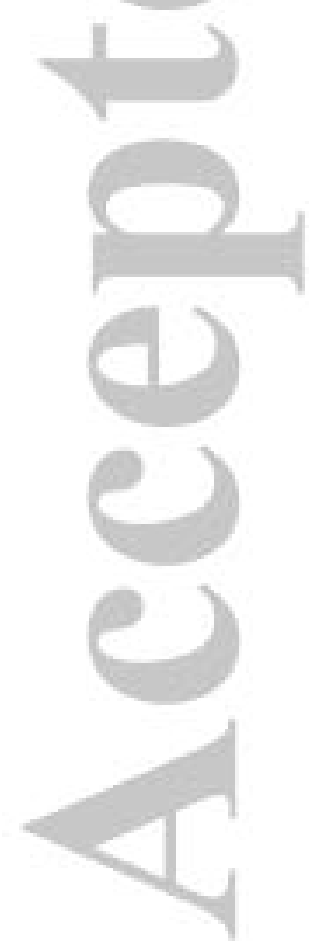

